UC-70

Issued: August 1987

LA--11070-MS

DE87 012415

\title{
Lateral Continuity of Sorptive Mineral Zones Underlying Yucca Mountain, Nevada
}

\author{
Katherine Campbell
}

\section{DISCLAIMER}

\begin{abstract}
This report was prepared as an account of work sponsored by an agency of the United States Government. Neither the United States Government nor any agency thereof, nor any of their employees, makes any warranty, express or implied, or assumes any legal liability or responsibility for the accuracy, completeness, or usefulness of any information, apparatus, product, or process tisclosed, or represents that its use would not infringe privately owned rights. Reference herein to any specific commercial product, process, or service by trade name trademark, manufacturer, or otherwise does not necessarily constitute or imply its endorsement, recommendation, or favoring by the United States Goyernment or any agency thereof. The views and opinions of authers expressed herein do not necessarily state or reflect those of the United States Government or any agency thereof.
\end{abstract}

\section{MASTER}

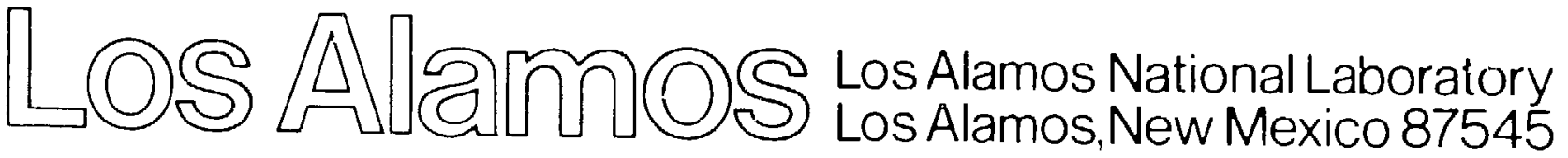




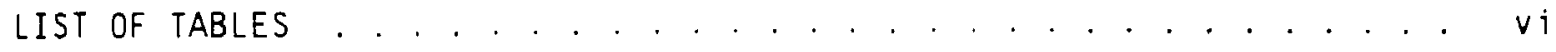

LIST OF FIGURES . . . . . . . . . . . . . . . . . . . . . . . . . vii

ABSTRACT . . . . . . . . . . . . . . . . . . . . . . . . . . 1

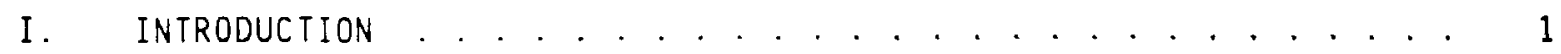

II. REVIEW OF X-RAY DIFFRACTION DATA ............... 5

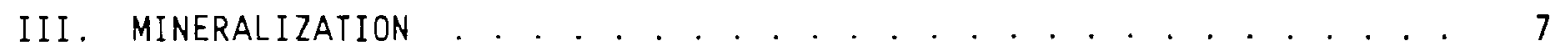

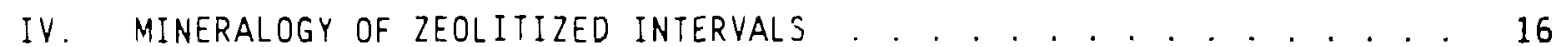

A. CHn (zeolitized) . . . . . . . . . . . . . . . . . . 19

B. CFUn ....................... . . . 25

ᄃ. CFMn ................... . . . 27

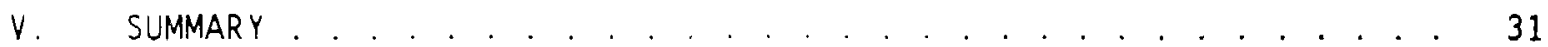

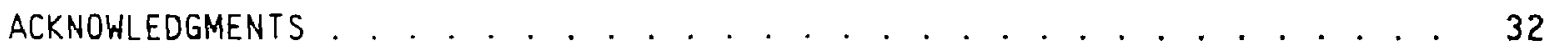

APPENDIX A: SUMMARY TABLE GF XRD DATA BY FUNCTIONAL UNIT FROM DRILL

HOLES AND STRATA CONSIDERED BY ORTIZ ET AL. . . . . . . . . . . 33

APPENDIX B: ASSIGNMENT OF SAMPLES FROM DRILL HOLES AND DEPTHS NOT

COVERED BY THE FUNCTIONAL STRATIGRAPHY OF ORTIZ ET AL (1985) . . . 36

APPENDIX C: SUMMARY TABLE OF XRD SAMPLES FROM ZEOLITIZED UNITS . . . . . 39

APPENDIX D: CONSTRUCTION OF PROBABILISTIC MODELS .......... 41

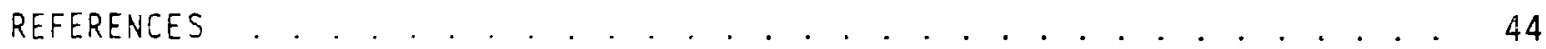




\section{LIST OF TABLES}

1. MODIFICATIONS OF ORIGINAL DATA. . . . . . . . . . . . . . . . . . . . 7

2. MODELS FOR ABUNDANCE OF MINERALS IN CHO . . . . . . . . . . . . . . . 22

3. MODELS FOR CLINOPTILOLITE/MORDENITE DISTRIBUTION IN CHN AT $\mathrm{D}=0.5$. . . . . . . . . . . . . . . . . . . . . 24

4. MODELS FOR ABUNDANCE OF MINERALS IN CFUn. . . . . . . . . . . . . . . . 25

5. MODELS FOR CLINOPTILOLITE/MORDENITE DISTRIBUTION IN CFUN AT $\mathrm{D}=0.5$. . . . . . . . . . . . . . . . . 27

6. MODELS FOR ABUNDANCE OF MINERALS IN CFMn. . . . . . . . . . . . . . . 28 


\section{LIST OF FIGURES}

1. Orill holes in the vicinity of Yucca Mountain, with outiines of the exploration block and perimeter drift . . . . . . . . . . . . .

2. A comparison of the formal stratigraphic column at Yucca Mountain (column A) with the "functional stratigraphy" used in Ortiz et al. (1985) and in this report (column B)...........

3. Distribution of zeolites in XRO samples from cored holes and sidewall samples of nominally zeolitized units.

4. Distribution of glass in core and sidewall XRD samples from vitric units. . . . . . . . . . . . . . . . . . . . . . . . . .

5. Distribution of silica polymorphs in core and sidewall XRD samples from (a) zeolitized units, (b) vitric units, and (c) devitrified units

6. Distribution of alkali-feldspar in core and sidewall XRD samples from (a) zeolitized units, (b) vitric units, and (c) devitrified units

7. Projection of XRD data onto a plane in which the major mineralization types are well separated.

8. Projection of reclassified XRD data.................. . . 15

9. Distribution of total zeolites in XRD samples from (a) CHn, (b) CFUn, and (c) CFMn.

10. Projection of XRD data onto a plane in which the three major zeo!itized units are well separated

11. Proportion of total zeolitization composed of clinoptiloite

in samples from $\mathrm{CHn}$

12. Zeolitization of samples from CHn, plotted as a function of the depth in CHn, measured as a fraction of the distance between the top and the bottom of the unit.

13. Abundance of alkali-feldspar in samples from CHn, plotted as a function of depth in $\mathrm{CHn}$.

14. Models for zeolitization of the CHn unit at different depths, super imposed on a histogram of the samples from this unit.

15. Models for alkali-feldspar abundance in the CHn unit at different depths, superimposed on a histogram of the samples from this unit

16. Model for cristobalite abundance in the CHn unit, superimposed on a histogram of the samples from this unit.

17. Proportion of total zeolitization composed of clinoptilolite in samples from CFUn 
18. Zeolitization of samples from CFUn, plotted as a function of depth in CFUn, measured as a fraction of the distance between the top and the bottom of the unit.

19. Distribution of clinoptilolite in samples from CFMn by drill nole.

20. Distribution of quartz in samples from CFMn by drill hole.....

21. Models for clinoptilolite abundance in the CFMn units for the "north-east" holes J-13, UE-25b\#1H, USW G-2 and G-4, and the "south-west" holes USW GU-3, H-3 and G-4, superimposed on a histogram of the samples from this units. . . . . . . . . . . 30

22. Models for quartz abundance in the CFMn units for the "north-east" and "south-west" holes, superimposed on a histogram of the samples from these units. . . . . . . . . . . . . . . . . . . 
LATERAL CONTINUITY OF SORPTIVE MINERAL ZONES UNDERLYING YUCCA MOUNTAIN, NEVADA

by

Katherine Campbell

\begin{abstract}
Mineralogical investigations at Yucca Mountain in southwestern Nevada are part of the characterization of this site for a potential nuclear waste repository. This report analyzes compositional. data obtained by $x$-ray powder diffraction for several hundred samples from fourteen drill holes in the vicinity of Yucca Mountain. Mineralization is compared with the functional stratigraphy for the region proposed by ortiz et al. (1985). Three major zeolitized intervals below the Topopah Spring Member of the Paintbrush Tuff are of particular interest because of the ir potential to retard the transport of dissolved radionuclides. No significant lateral trends in total zeolitization within these units are noted in the neighborhood of the Exploration Block, but there are trends in the abundances of the individual zeolites. Much local variation that cannot be explained by either vertical or lateral trends is observed.
\end{abstract}

\title{
I. INTRODUCTION
}

Yucca Mountain, near the southwestern boundary of the Nevada Test Site in south-central Nevada (Fig. 1), is being studied to determine its suitability as a site for underground disposal of high-level radioactive waste. The studies of Yucca Mountain and vicinity are part of the Nevada Nuclear Waste Storage Investigations Project, which is managed by the Waste Management Project Office of the U.S. Department of Energy's Nevada Operations Office. These studies include a detailed analysis of the distributions of minerals along possible transport pathways away from the potential repository horizon. The analysis of mineral distributions is being done by powder $x$-ray diffraction (XRD), because the samples being analyzed are very fine grained and are not amenable to quantitative mineral analysis by optical methods. Quant itative XRD determinations of mineral abundances are being emphasized, using both core and drill cuttings samiples from drill holes in and around 


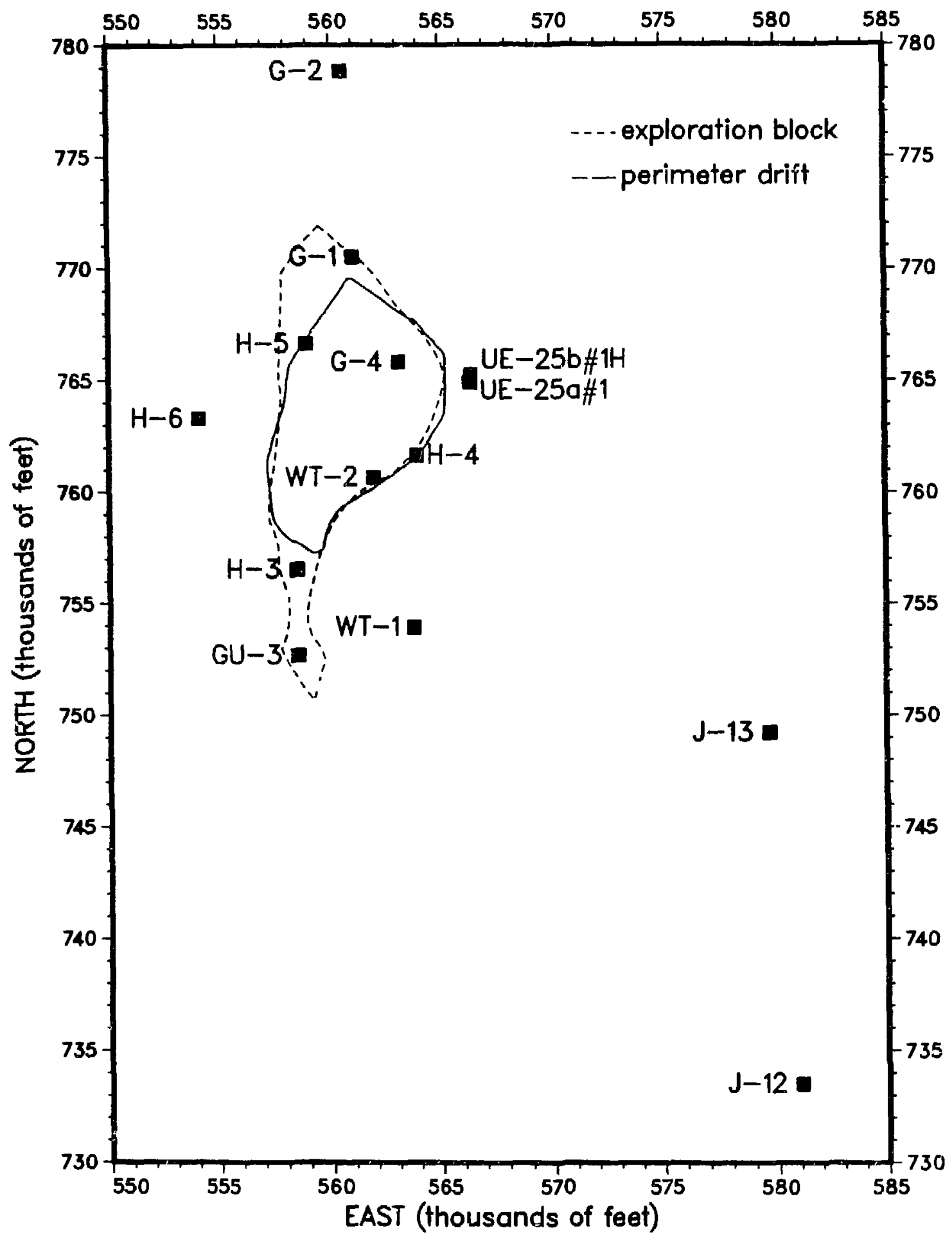

Figure 1. Drill holes in the vicinity of Yucca Mountain, with outlines of the exploration block and perimeter drift. The prefix "USW" has not been included on the hole designations. 
Yucca Mountain. Methods and data are summarized in Bish and Vaniman (1985) and Bish and Chipera (1986).

Because the rocks at Yucca Mountain will provide the ultimate containment of radioactive waste, it is important to have a firm knowledge of the distribution of mineral types. Those minerals that can provide enhanced containment through sorption (see Bish et al., 1984) are particularly important. Investigations have shown that the zeoilte minerals clinoptilolite and mordenite as well as the smectite clays have particularly high sorption ratios for many cationic radionuclides (Daniels, 1982).

The drilling data obtained from Yucca Mountain and vicinity have also been compiled into a "functional stratigraphy" by Ortiz et al. (1985), Fig. 2. These functional stratigraphic units are characterized by relatively homogeneous thermal/mechanical and hydrological properties. The classification developed by ortiz et al. is based primarily on lithologic logs and on the bulk thermal/mechanical properties of the tuff; only limited use is made of mineralogic data in delineating the zeolitized units. This report investigates the homogeneity of these functional units with respect to mineralogy. Can the tuffs below Yucca Mountain be modeled as simple stratigraphic slabs, each characterized by a single set of mineralogic parameters? What error distributions should be associated with these parameters? Is it possible to determine any lateral or vertical trends or correlations among the mineralogical components that would help to narrow these distributions and improve prediction within smaller areas?

The answers to these questions will be important in modeling the Yucca Mountain site for probabilistic calculation of overall retardation by sorption of radiologic cations along a large number of possible pathways to the accessible environment. In this report we consider in detail the mineralogy of the three major zeolitized intervals in the Tertiary Tuffs below the Topopah Spring Member of the Paintbrush Tuff at Yucca Mountain. These are intervals of nonwelded, partially welded and bedded tuffs, in which alteration has occurred, between less altered densely welded units. Some vertical and lateral trends within these units can be modeled, and preliminary stochastic models to account for the remaining variability within units are proposed.

Following a review of the available XRD data (Sec. II), a comparison of samples from cored holes with the "mineralization" of the functional units defined by Ortiz et al. (i.e., "zeolitized", "vitric" or "devitrified") is 
A

B

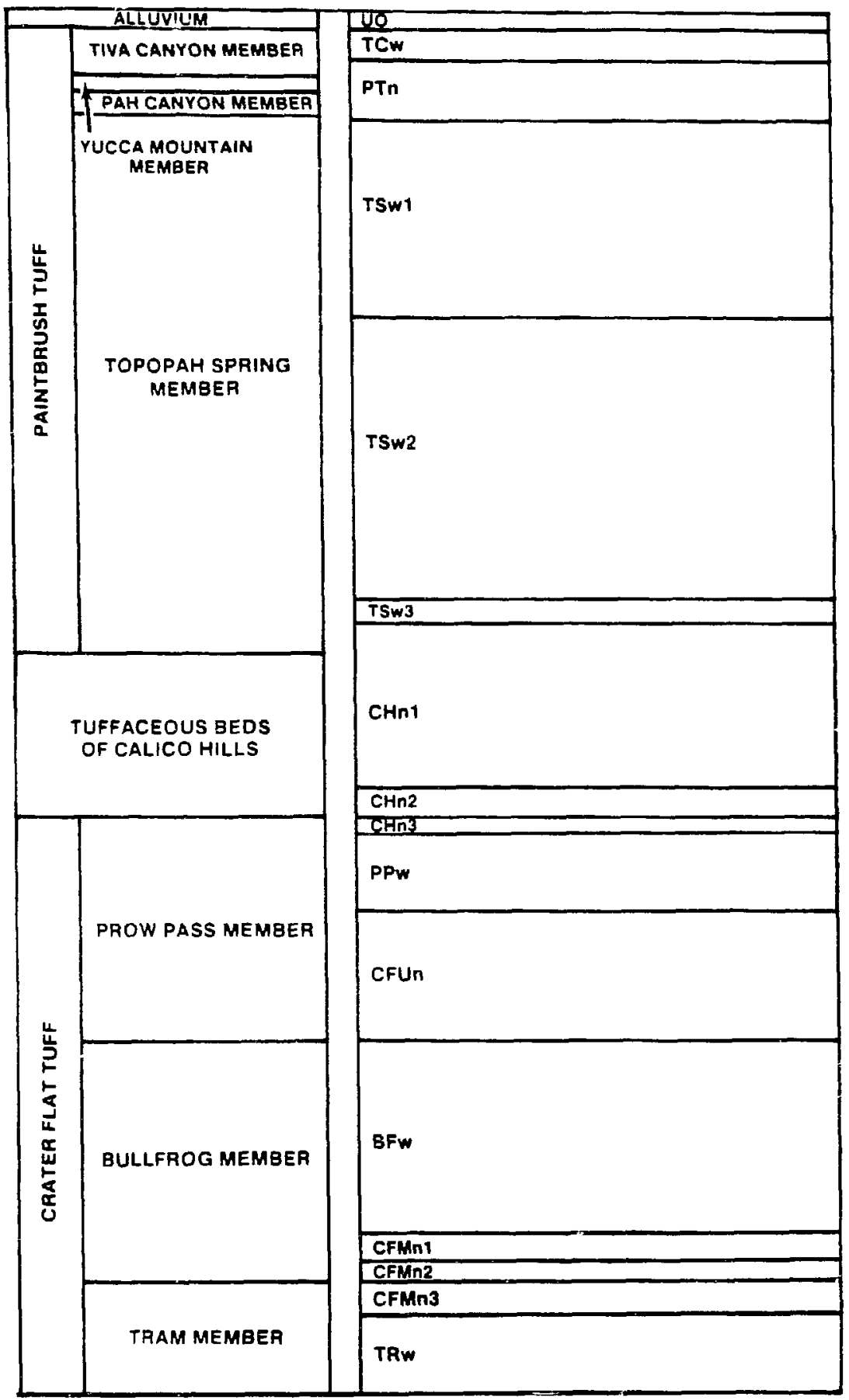

Figure 2. A comparison of the formal stratigraphic column at Yucca Mountain (column A) with the "functional stratigraphy" used in Ortiz et al. (1985) and in this report (column B). This figure is modified from Ortiz et al. (1985), p. 44. 
undertaken (Sec. III). Based on the results of this investigation, it will be possible both to classify some samples from holes and depths not considered by Ortiz et al. and to ascertain that samples from cuttings are not apparently seriously contaminated by material from overlying units or otherwise less reliable than samples from cores and sidewall samples. In Sec. IV the mineralogy of the three major zeolitized units beneath the host rock for the proposed repository is considered in greater detail, and some preliminary stochastic models are proposed. The major conclusions are summarized in Sec. V.

\section{REVIEW OF X-RAY DIFFRACTION DATA}

The $x$-ray diffraction data come from fourteen drill holes in the vicinity of Yucca Mountain (see Fig. 1). Five cored holes were included in the summary by Bish and Vaniman (1985): USW G-2, GU-3, G-4, H-6, and UE-25b\#1H. Data from cored holes J-13, UE-25a\#1 and USW G-1 are discussed by Bish and Chipera (1986). Cuttings and some sidewall sample are available from the remaining holes (USW H-3, H-4,H-5, WT-1, WT-2 and J-12), plus a few core samples from the bottom of USW WT-2. These data are also discussed by Bish and Vaniman (1985). The available samples come from all strata defined by ortiz et a 1. (1985) except the topmost "undifferentiated overburden" above the welded, devitrified Tiva Canyon Member of the Paintbrush Tuff. Several samples come from below the base of the lowest unit listed for the corresponding hole in Tables B.1 through B.11 of the report by Ortiz et al. Appendix A summarizes the data for the XRD samples that come from the drill holes and units described in the Ortiz report (a total of 473 samples).

The stratigraphic units shown in Fig. 2 are defined in Table 1 of Ortiz et al., and we follow the nomenclature of that report. The tuffs underlying Yucca Mountain are divided in this "functional" stratigraphy intc a sequence of devitrified tuffs alternating with less densely welded, non-welded and bedded vitric or zeolitized strata. For the potentially zeolitized (i.e., nondevitrified) units PTn, TSW3, CHn1, CHn2, CHn3, CFUn, CFMn1, CFMn2 and CFMn3, the mineralization assigned by Ortiz et al. is determined by whether or not a sample lies above or below the "top of prevalent zeolitization", the TZZ surface. Within the area studied by Ortiz et al., this surface lies below the Topopah Spring Member of the Paintbrush Tuff (TSW) and above the Crater Flat nonwelded units (CFUn and CFMn) but can intersect the Calico Hills (CHn) 
units so that $\mathrm{CHn} 1, \mathrm{CHn} 2$ and $\mathrm{CHn} 3$ contain both "vitric" and "zeolitized" subunits.

Not included in Appendix $A$ are samples from orill holes $\mathrm{J}-12, \mathrm{~J}-13$, USW WT-1 and WT-2 (which were not studied by Ortiz et al.--96 XRD samples) or from below the base of the lowest unit tabulated in that report (a total of 179 samples from USW G-1, G-2, GU-3, G-4,H-3. H-6 and UE-25b\#1H). Also excluded are samples labeled by either Bish and Vaniman (1985) or Bish and Chipera (1986) as coming from fractures, veins, cavities, inclusions, etc. The following minerals were measured in each sample: smectite, mica, alass; alkali-felaspar, calcite, hematite, wïe çesites sillopílolite, murdenite and analcime, and the silica polymorphs quartz, cristobalite (sometimes conibined with opal) and tridymite. As noted in Appendix A, some of these minerals were either below detection limit or not present at all in some holes.

Data in the reports by Bish and Vaniman (1985) and by Bish and Chipera (1986) are sometimes reported as interval estimates (e.g., 20-40\% alkalifeldspar, $0-5 \%$ quartz) and sometimes with such notations as "trace" or " $1 \%$ " or "<1\%". For analysis, intervals are replaced by their midpoints and the various notations for trace amounts by $0.5 \%$. Where no measurement is reported, as noted at the end of Appendix $A$, the amount of that mineral present in a sample is taken to be zero. Another feature of the data is that generally, although not uniformly, the estimates of measurement error increase significantly with the abundance of a mineral, being reported typically as $\pm 10 \%$ for measurements above $50 \%, \pm 5$ to $8 \%$ for measurements between 20 and $50 \%$, down to $\pm 1 \%$ for measurements of a few parts per hundred. Both to reduce this systematic variation and to normalize the distributions of the measurements, a square-root transformation is used prior to the application of statistical techniques chat assume homoscedasticity and approximate normality of the data.

Simple tabulation of the data reveals a few anomalies amons the samples summarized in Appendix A. Because of these anomalies, four borderline samples were reclassified into different strata (in all cases, these samples lay within the uncertainties in the estimated contacts reported in Appendix $B$ of the report by Ortiz et a 1., 1985), and three were assigned a weight of zero for some of the succeeding analyses. These modifications are summarized in Táble 1 . 
TABLE 1 .

MODIFICATIONS OF ORIGINAL DATA

\begin{tabular}{|c|c|c|c|c|}
\hline Sample & $\begin{array}{l}\text { Classific } \\
\text { by Ortiz }\end{array}$ & $\begin{array}{l}\text { ation } \\
\text { et al. }\end{array}$ & Action* & Explanation \\
\hline G1-2544 & CFMn] & $z$ & $R$ & $\begin{array}{l}\text { Near boundary, contains no } \\
\text { zeolites. Reclassified as } \\
\text { BFw. }\end{array}$ \\
\hline G1-2765 & $T R W$ & $d$ & $R$ & $\begin{array}{l}\text { Near boundary, contains } 15 \% \\
\text { zeolites. Reciass ified as } \\
\text { CFMn3. }\end{array}$ \\
\hline$G 1-3018$ & $T R W$ & $d$ & $R$ & $\begin{array}{l}\text { Near boundary, contains } 10 \% \\
\text { zeolites. } \\
\text { below TRw. }\end{array}$ \\
\hline$G A-15 ; 2$ & $\mathrm{CHnl}$ & 2 & $R$ & $\begin{array}{l}\text { Near boundary, contains only } \\
\text { Lrace zeolites, } 40 \% \text { glass. } \\
\text { Reclassified as CHnl vitric. }\end{array}$ \\
\hline$G 2-762$ & PTn & $v$ & $W$ & Contains $83 \%$ zeclites. \\
\hline $45-1966$ & $\mathrm{CHn} 3$ & $z$ & $W$ & $\begin{array}{l}\text { Contains no zeolites and } 75 \% \\
\text { glass. }\end{array}$ \\
\hline H6- 1512 & $\mathrm{CH} n 3$ & v & W & $10 \%$ glass, $36 \%$ zeolites. \\
\hline
\end{tabular}

* $R=$ reclassified. $W=$ set weight to zero.

III. MINERALIZATION

Ortiz et al. (1985) classify the tuffs below Yucca Mountain into three major variants: vitric, zeolitized and devitrified. In this section we address the question of how well this classification can be reproduced using only the XRD data. Does this subdivision appear to correspond to a natural clustering of the samples? Are the clustars well defined and relatively homogeneous, or are the boundaries between them 111 defined?

The depths from which core and sidewall samples are taken are known with reasonable accuracy. However, cuttings are collected in ten foot intervals and furthermore are sometimes contaminated by material from overlying strata. Therefore this analys is uses only core and sidewall samples.

The classification by Ortiz et al. appears to be a natural one. Some anomalies are observed: a couple of boundaries do not appear to correspond 
precisely to the location given by Ortiz et al., and some samples associated with the smectite bearing intervals at the top of the vitric Upper Paintbrush nonwelded unit (PTn) and the top of the Topopah Spring vitrophyre (TSw3) (see Bish and Vaniman, 1985, Pp. 9-10) do not match any of the three types of mineralization very well. In general, however, the natural clustering is good enough to provide a preliminary classification of samples from wells or depths not considered by Ortiz et al. (specifically, samples from J-12, J-13 and USW WT-1 and WT-2, and a few from the bottom of USW GU-3, G-4 and H-3) and to verify that in fact samples from drill cutings are not seriously contaminated and can be classified (at least into these three broad categories) just as well as those from core or sidewall sampling. This preliminary classification will make it possible to expand the set of usable samples in the next section, in which the zeolitic intervals underlying Yucca Mountain will be characterized.

Not surprisingly, samples from zeolitized units are generally distinguished by the presence of more than $15 \%$ zeolites (clinoptilolite, mordenite and/or analcime; see Fig. 3). But zeolites in this abundance are rarely found in samples from other urits, except for minor local zeolitization in vitric

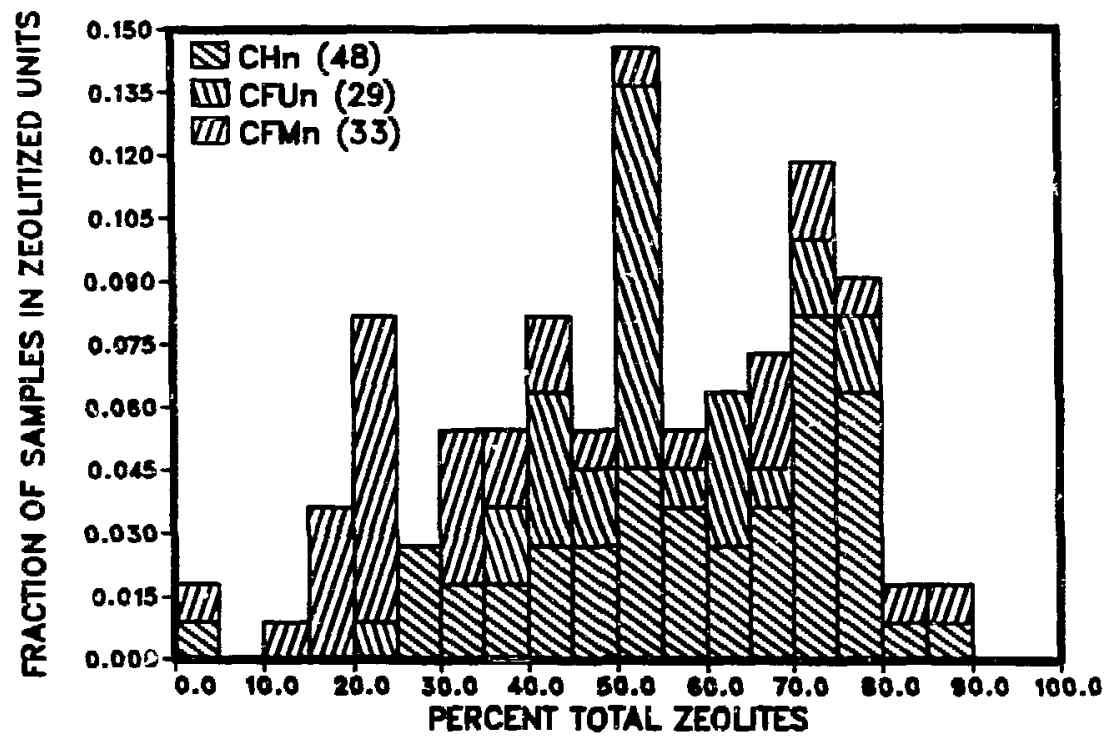

Figlire 3. Dist-ibution of zeolites in XRD samples from cored holes and sidewall samples of nominally zeolitized units. 


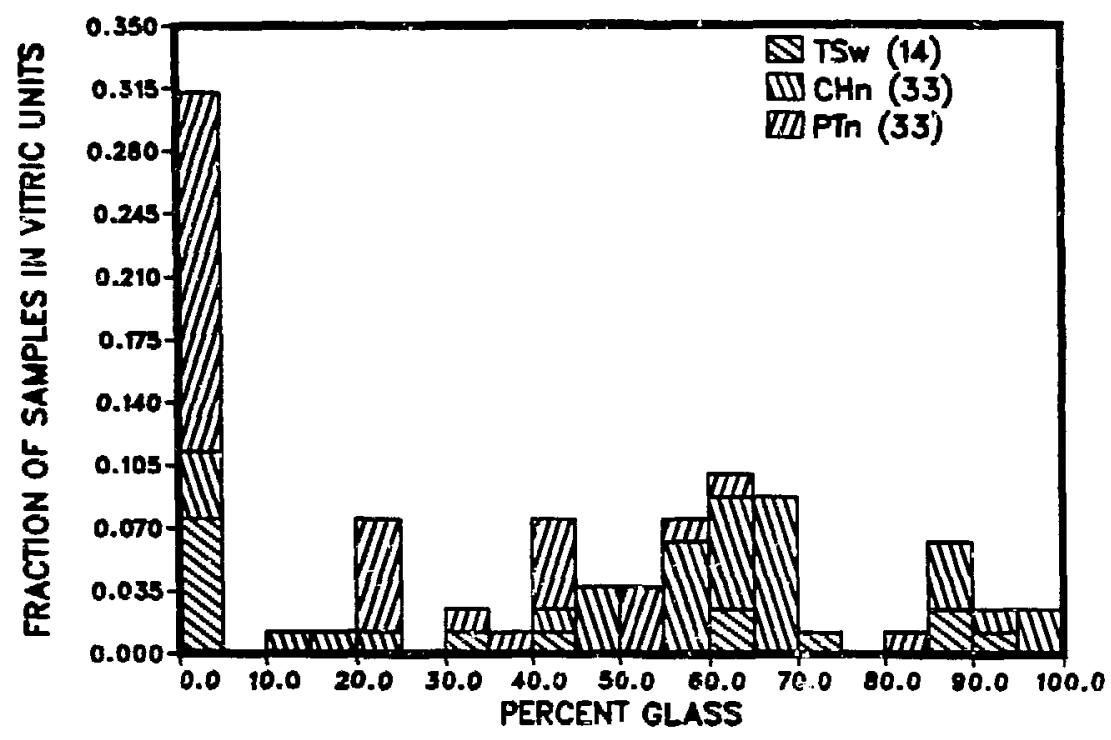

Figure 4. Distribution of glass in core and sidewall XRD s mples from vitric units.

units (especially in the lower half of PTn in G -2 and in the vitrophyre TSw3, where it is associated with the narrow smectite-bearing interval). Glass is found only in vitric units (Fig. 4), except for the two samples from USW H-5 and H-6 that were noted in Table 1 and one sample from J-13. However, about $35 \%$ of these nominally vitric samples have no glass. Some of these samples are partially zeoititized or have very small amounts of alkali-feldspar and/or silica polymorphs, factors that serve to distinguish them from devitrified samples (see Figs. 5 and 6 ), but many are indistinguishable from samples from nominally devitrified units. The latter will be considered in greater detail shortly.

Figure 7 is a projection of the tweive-dimensional data vectors (where the square roots of the abundances of the twelve measured minerals are the coordinates for each sample) onto a plane that is optimally selected to separate samples according to the nominal mineralization of the unit from which they were taken. Each point denotes the projection onto this plane of an individual sample. As we would expect, the first (horizontal) dimension of 


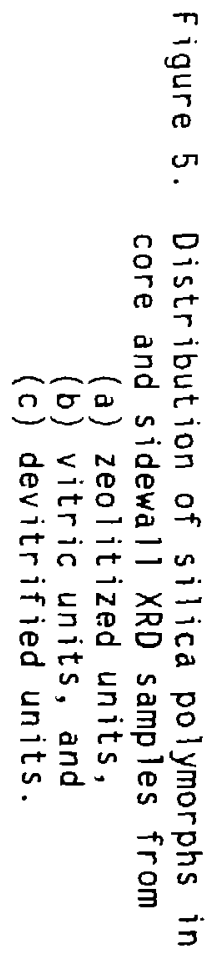

FRACTION OF SAMPLES IN DEVITRIFIED UNITS

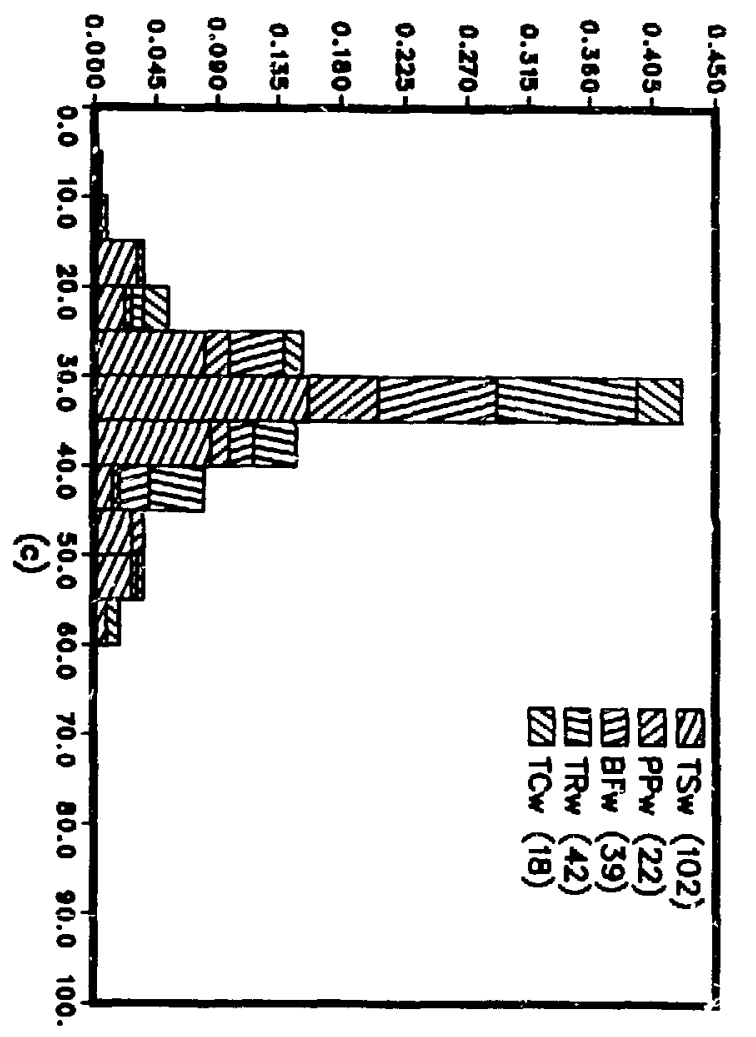

FRACTION OF SAMPLES IN ZEOLITIZED UNITS
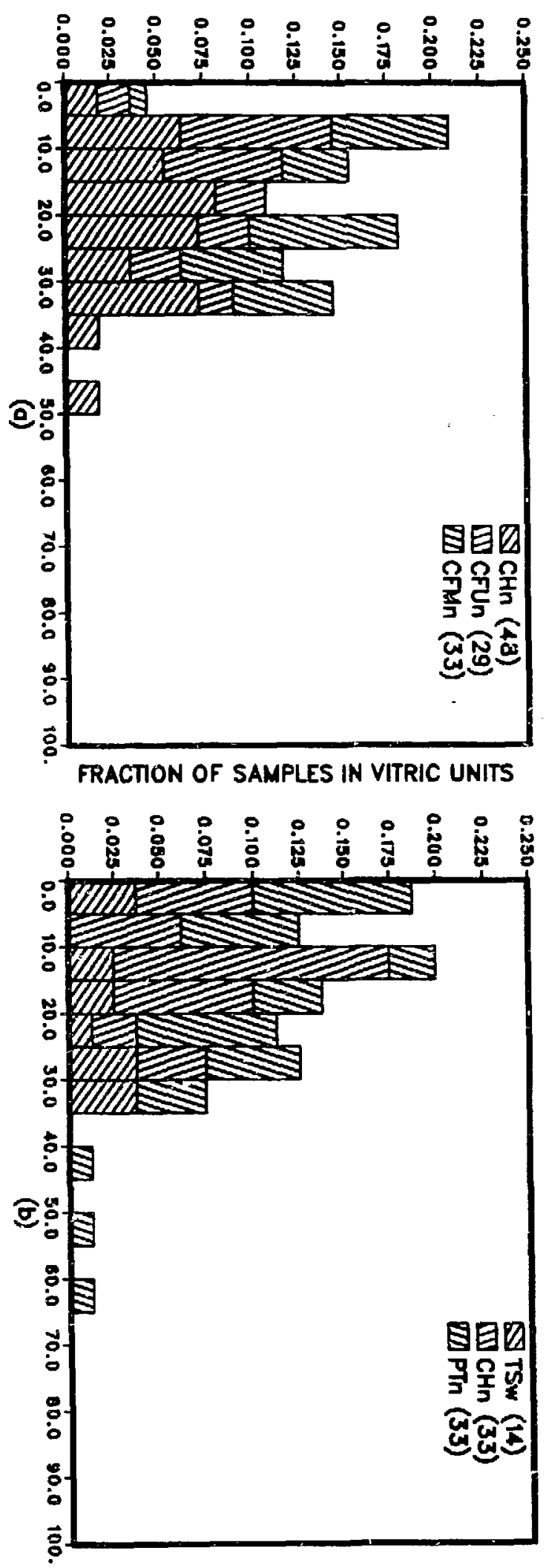
FRACTION OF SAMPLES IN ZEOLTIZED UNITS
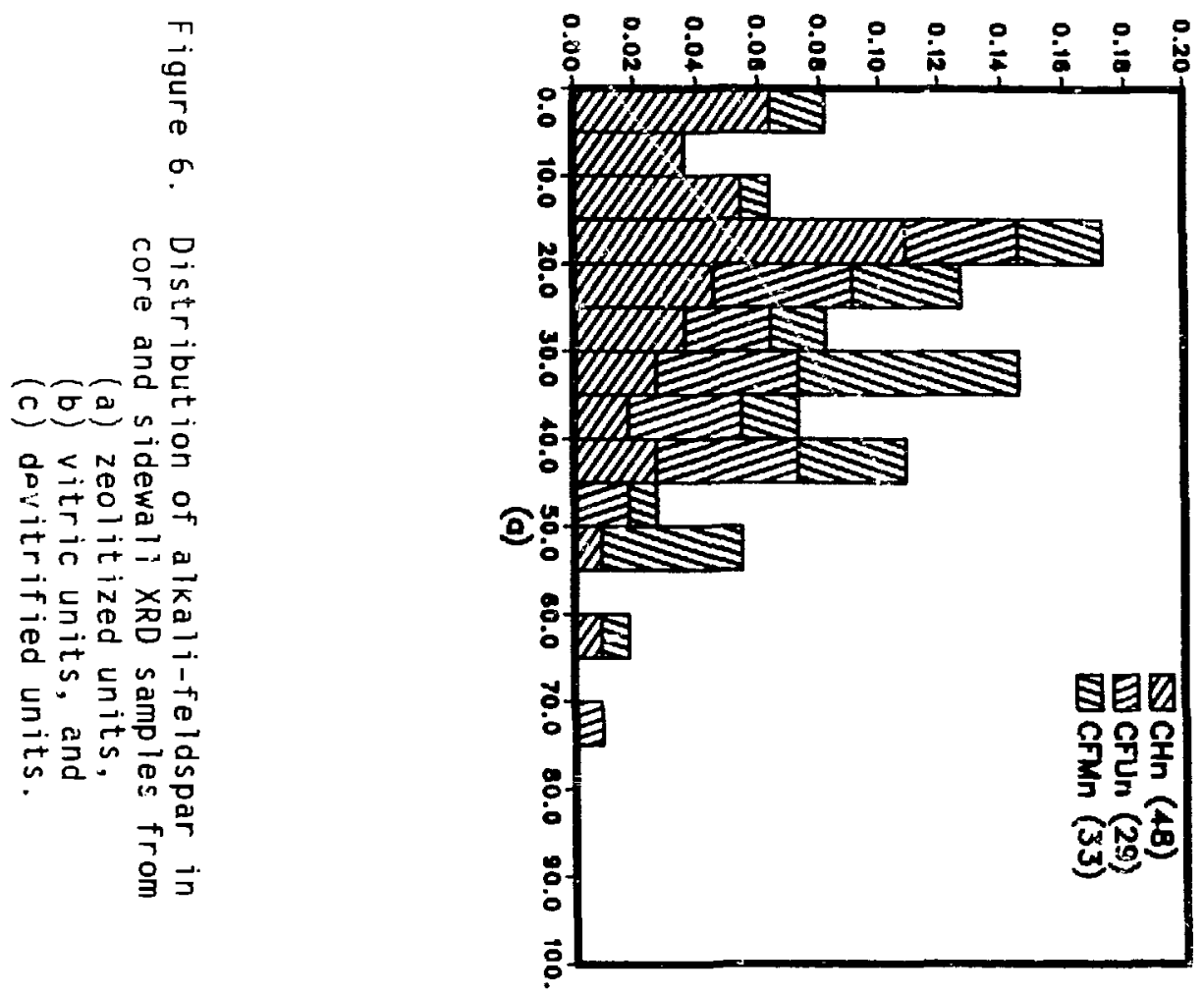

FRACTION OF SAMPLES IN DEVITRIFIED UNITS

FRACTION OF SAMPLES IN VITRIC UNITS
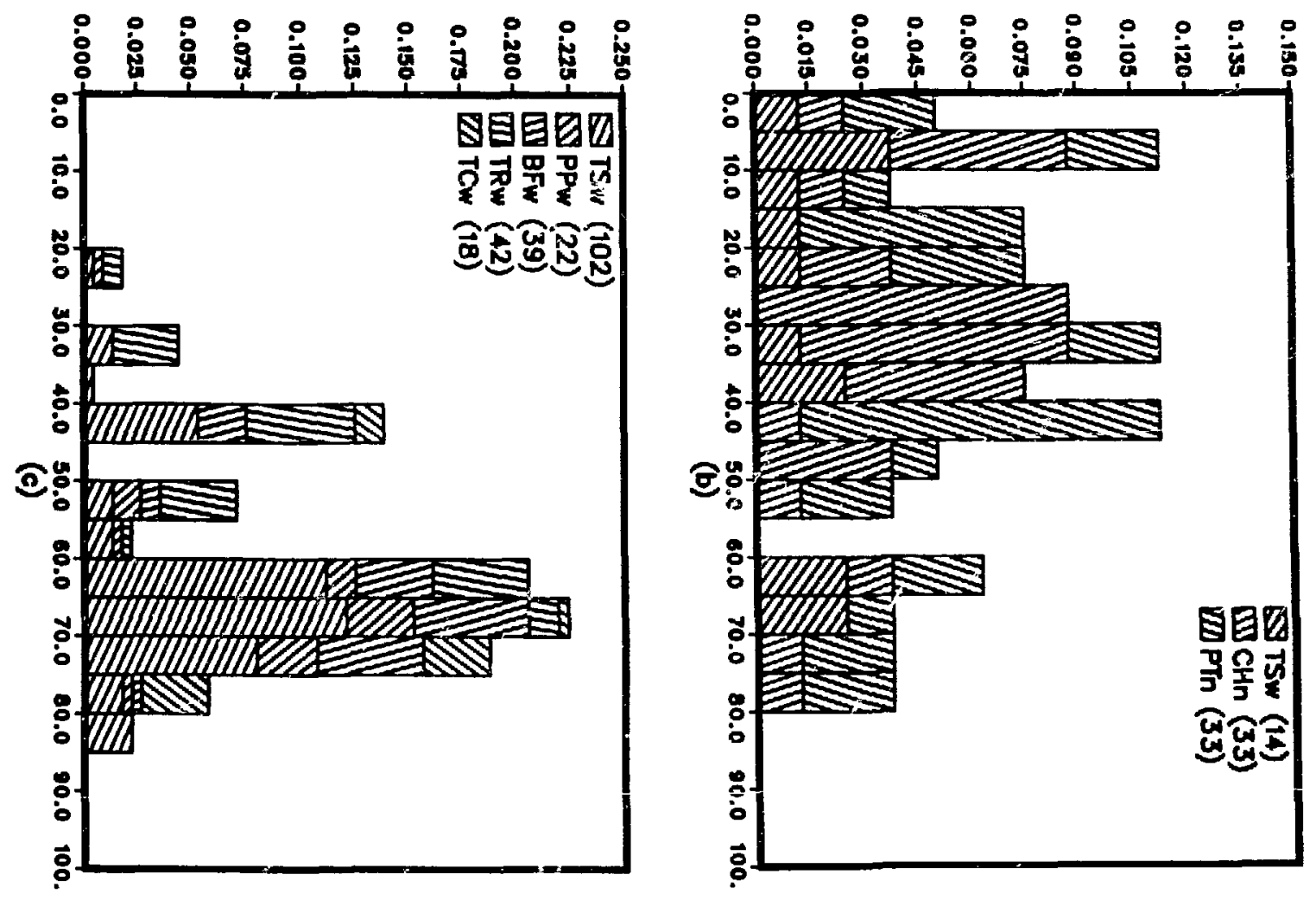
this projection is largely a function of the zeolites in the sample, and the second depends mostly on the glass content. Alkali-feldspar and the silica jolymorphs are also factors, as suggested above. In this projection the zeolitic units are pulled well away from the remaining samples, and the samples from the devitrified units occupy a compact area in the upper lefthand corner, but this area is invaded by a number of nominally vitric samples. Most of these latter samples are taken near a boundary with a devitrified unit, the boundary in every case being determined from the 1ithologic log, according to Ortiz et al. (1985; see their Appendix B). On the basis of the mineralogy alone, we would be inclined to move some of these boundaries, in most cases only a few feet, but in the case of the TCW-PTn boundary in USW G-2 (see below), by as much as 100 feet. Quite a number of these misplaced samples also correspond to the thin smectite-bearing intervals mentioned earlier, which are not distinguished by Ortiz et al. However, there are not yet enough samples from these intervals to characterize a fourth mineralogical variant. Formal discriminant analysis consistently misclassifies these samples, although their inclusion in the data set used to calibrate such a classifier does not affect the resulting calibration significantly.

The anomalies revealed by fig. 7 and by furmal discriminant analysis will now be considered in detail.

--Sample G1-1286 from the bottom of TSW2 in USW G-1: Discriminant analysis classifies this sample as vitric. It falls within the smectite-bearing interval between TSW2 and the vitrophyre TSw3 and for consistency should be assigned to TSw3, like other such samples.

--Three samples, G2-230, G2-270 and G2-304, from the top of PTn in USW G-2: The transition between $T C W$ and PTn in G-2 is placed at a depth of 220 feet on the basis of the lithologic log (see Ortiz et al., 1985, pp. 48 and 60). However, no glass appears in any sample until G2-338, and mineralogically these three samples are indistinguishable from the TCW samples immediately above, with 30 to $50 \%$ each of cristobalite and alkali-feldspar. The next tihree samples from G-2, G2-331, G2-338 and G2-358, contain substantial amounts of smectite and appear to be associated with the smectite-rich interval at the top of PTn.

--Sample G2-770 at the bottom of PTn: This is only one foot above the assigned contact with TSWl and is consistently classified as devitrified. 

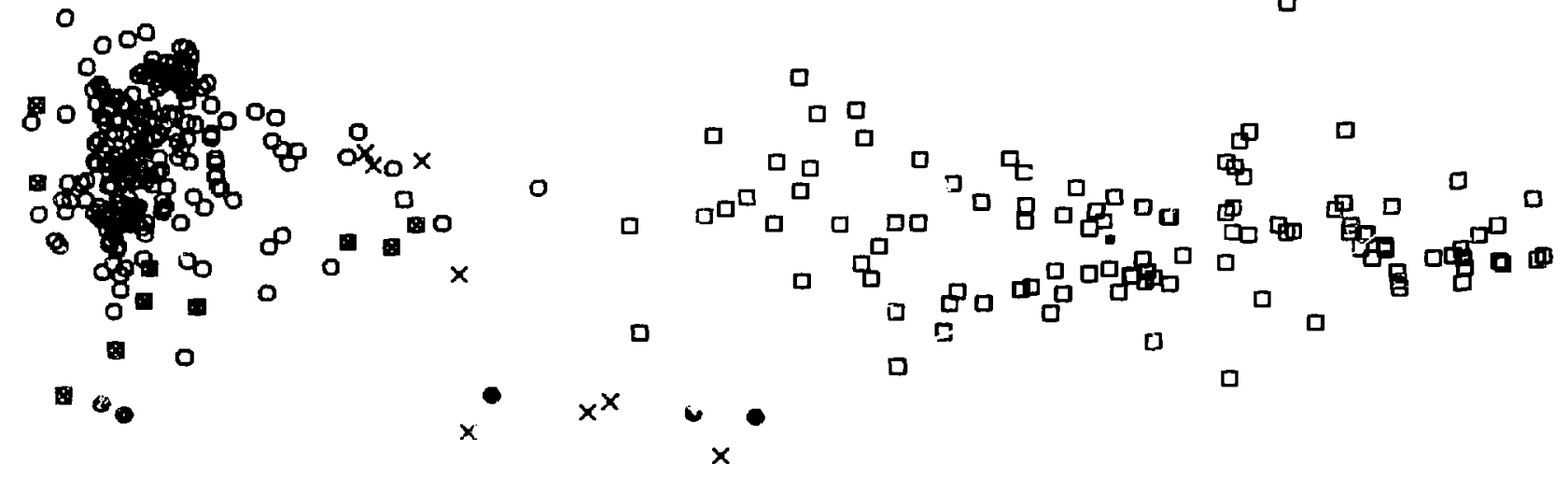

口

口

\section{o Devitrified}

$\times$ Vitric

Nominally vitric

- Smectite layer

$\square$ Zeolitized

« Weight=0

Figure 7. Projection of XRD data onto a plane in which the major mineralization types are well separated. This shows that the XRD data fall naturally into these three categories but also highlights a number of minor anomalies, which are discussed in the text. 
--Five samples, G3-410, G3-414, G3-418, G3-424 and G3-429, from the bottom of PTn in USW GL-3: The transition to TSw1 was assigned at 430 feet, based on the lithologic log. However, no glass is observed in any of these samples. The alkali-feldspar content is $65 \%$ or more below 414 feet, and statistical classifiers consistently classify all five as devitrified.

--Three samples, G4-1299, G4-1301 and G4-1310, from the top of the vitrophyre in USW G-4: These are frequently misclassifind as devitrified, and the next sample, G4-1314, has a large smectite component, suggesting that the top of the vitrophyre should be taken at about a depth of 1312 feet, with these three samples reassigned to TSWR.

If the samples a-e reclassified as suggested above, then the resulting split in a projection similar to that of $F$ ig. 7 separates thi mineralizations somewhat more cleanly (see Fig. 8). Formal discriminant analyses calibrated on randomly selected subsets of about $80 \%$ of the data misclassify, on the average, about $5.6 \%$ of the remaining data, whereas a similar test based on the original classification results in an average misclassification rate of more than $7 \%$.

Drill cuttings from $\mathrm{H}-3, \mathrm{H}-4$ and $\mathrm{H}-5$ and samples from drill holes or depths not considered by Ortiz et al. (holes J-12, J-13, USW WT-1 and WT-2 and a few deep samples from USW GU-3 and G-4) were classified into the three mineralization types using a quadratic discriminant function calibrated with the reclassified data. The results are sufficiently consistent to allow us to place at least some boundaries in the wells not considered by ortiz et al., although of course this discriminant does not distinguish boundaries within zeolitized, vitric or devitrified units such as the TSw1/TSw2 or TSw3/CHn(v) boundaries. These preliminary classifications are shown in Appendix B. With very few exceptions, drill cuttings were classified as prescribed by ortiz et. al., indicating that these samples are no less reliable, at least with respect to these broad mineralization categories, than those from core and sidewall samples taken from precisely known depths In view of these results, samples from drill cuttings and wells not considered by ortiz et al. will be used, together with the core and sidewall samples, to characterize the sorptive mineral zones in the tuffs underlying Yucca Mountain and to investigate lateral and vertical continuity and trends within these zones. 


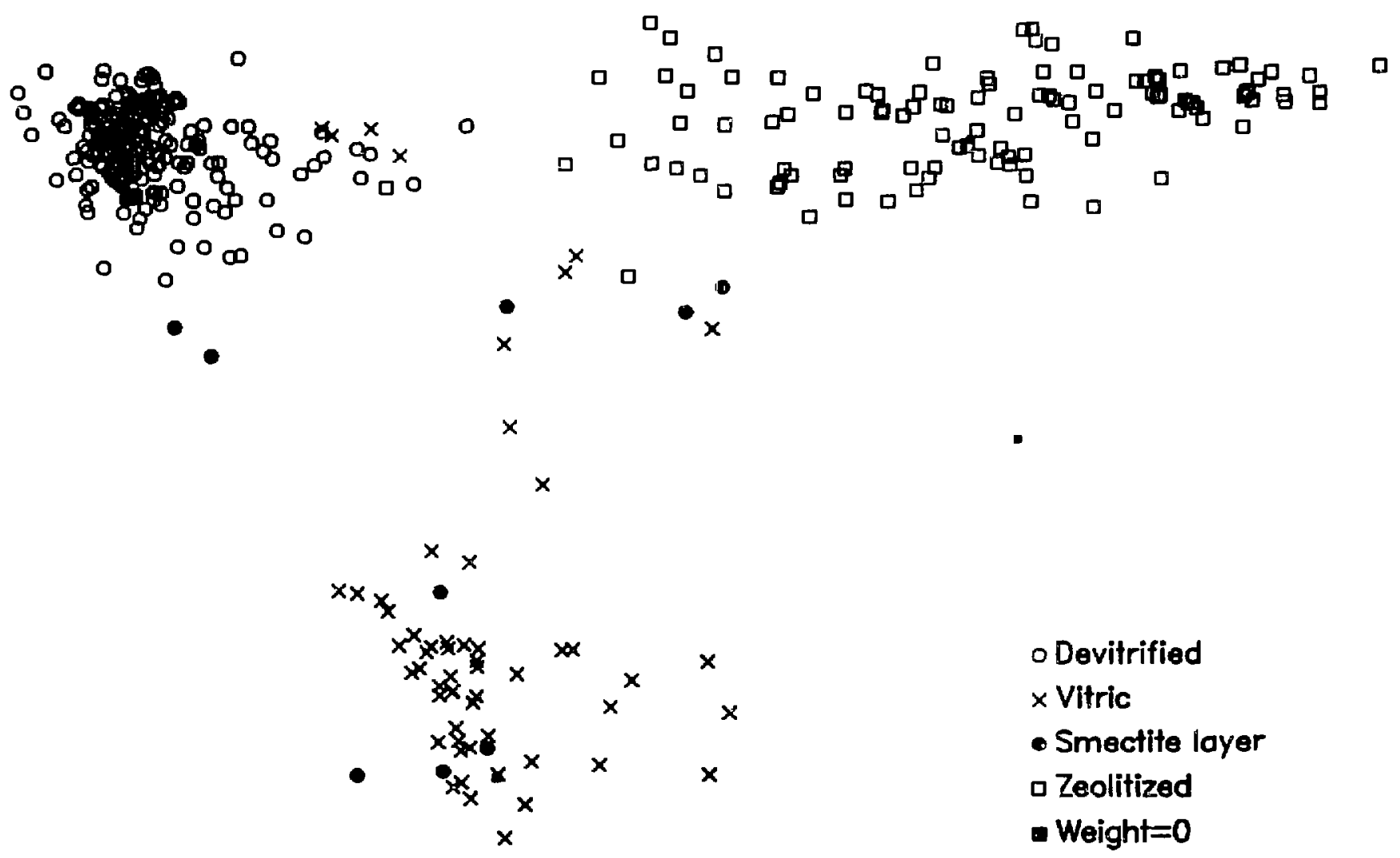

Figure 8. Projection of reclassified XRD data. In particular, several samples from neighboring devitrified units. 


\section{MINERALOGY OF ZEOLITIZED INTERVALS}

As seen in the preceding section, zeolites are indeed concentrated in the units labeled "zeolitic" by Ortiz et al. Using the drill cuttings and the samples classified as zeolitic in J-12, J-13, USW WT-1 and WT-2 at the end of the preceding section, there are 145 samples from these units; see Appendix $C$. Samples from CHn and CFMn in J-12, J-13, USW WT-1 air WT-2 could not be classified into subunits in the preceding section, and the precise location of the contacts between zeolitized an: i.unzeolitized units is in some cases very poorly determined without aditional logs of these wells.

Wich a couple of exceptions, samples from these zeolitic units contain at least $10 \%$ zeolites (clinoptilolite, mordenite and/or analcime), whereas few samples from other units contain more than $10 \%$ zeolites. (A small number of zeolitic samples were noted in the vitric Upper Paintbrush nonwelded unit and in the smectite-bearing interval at the top of the Topopah Spring vitrophyre.) However, there is a large range of zeolitization (see fig. 9), decreasing on the average with increasing depth but covering a wide range in each unit. Cristobalite concentration also decreases with depth, and there is more quartz in the CFMn units than in higher units and less alkali-feldspar in the $\mathrm{CH}$ units than in lower units. All of these factors contribute to the differentiation among the units that is illustrated in Fig. 10. (Figure 10, like Figs. 7 and 8 , is a projection of the samples from zeolitized units onto a plane, which in this case has been chosen optimally for the purpose of separating the three zeolitized units.)

Examination of $F i g .10$ suggests that a case might be made that the mineralogy of these units is better correlated with the formal geologic stratigraphy (i.e., column $A$ in Fig. 2) than with the functional stratigraphy defined by Ortiz et al. Mineralogically, for example, CHn1 and CHn2, within the tuffaceous beds of the Calico Hills, are indistinguishable, while as shown in Fig. 10, samples from $\mathrm{CHn}^{3}$, at the top of the Prow Pass Member of the Crater Flat Tuff, are more like the top 80 to $90 \%$ of CFUn, at the bottom of the Prow Pass Member. Ortiz et al. do not separate the Prow Pass and Bullfrog components of CFUn, but a few samples at the bottom of CFUn in fact are mineralogically like CFMn1 samples in Fig. 10. The middle Crater Flat units, CFMn1, CFMn2 and CFMn3, are also fairly distinci from one another; the lowest of these three belongs to the Tram Member of the Crater Flat Tuff, ard the other two belong to the Bullfrog Member. 
FRACTION OF SAMPLES IN CHn

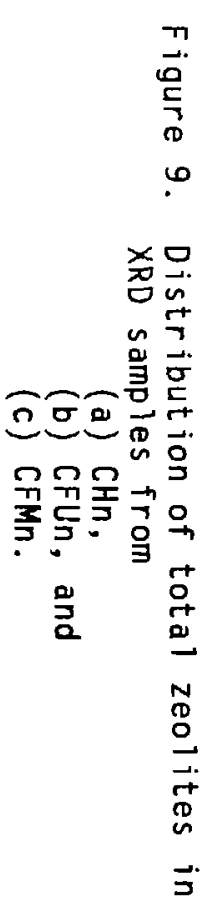

FRACTION OF SAMPLES IN CFMn

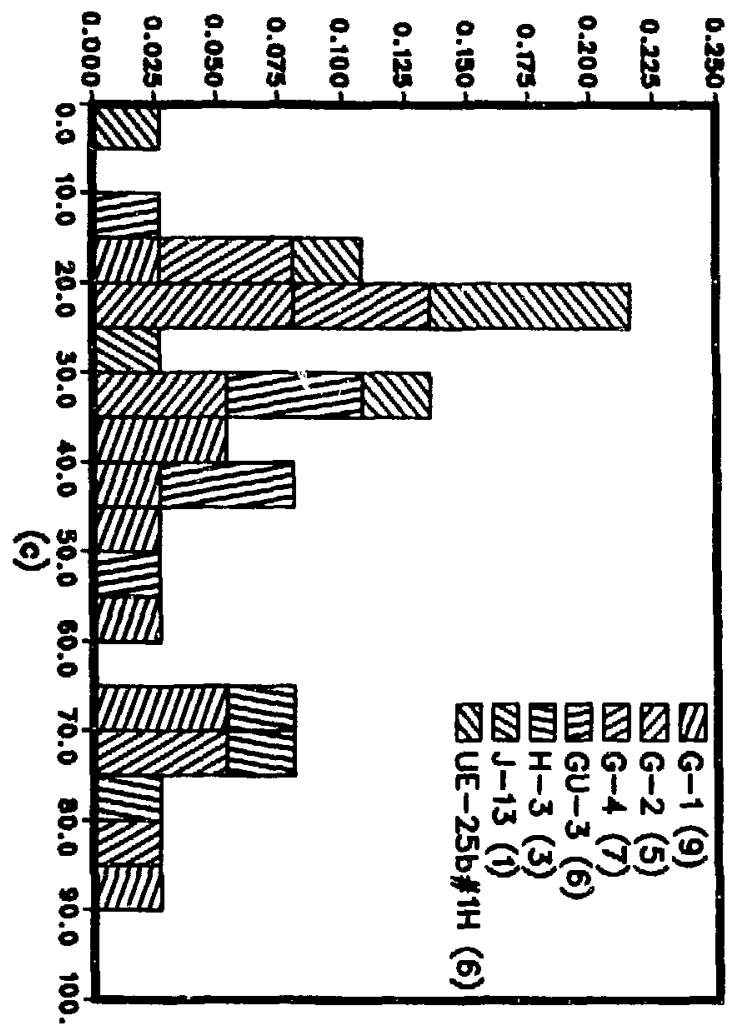

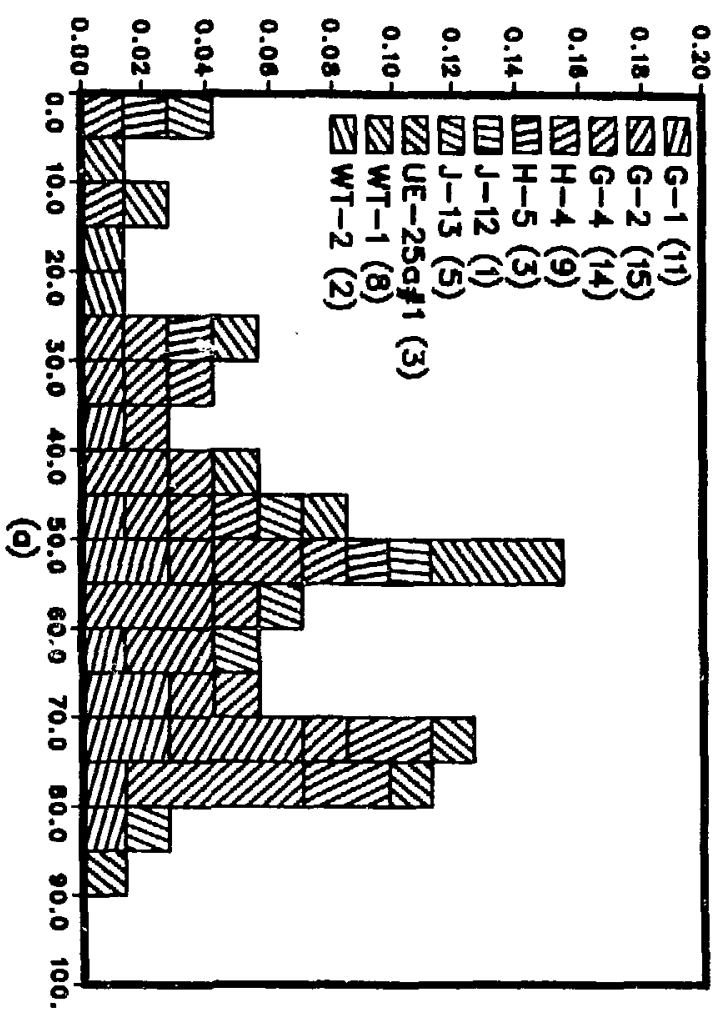

FRACTION OF SAMPLES IN CFUn

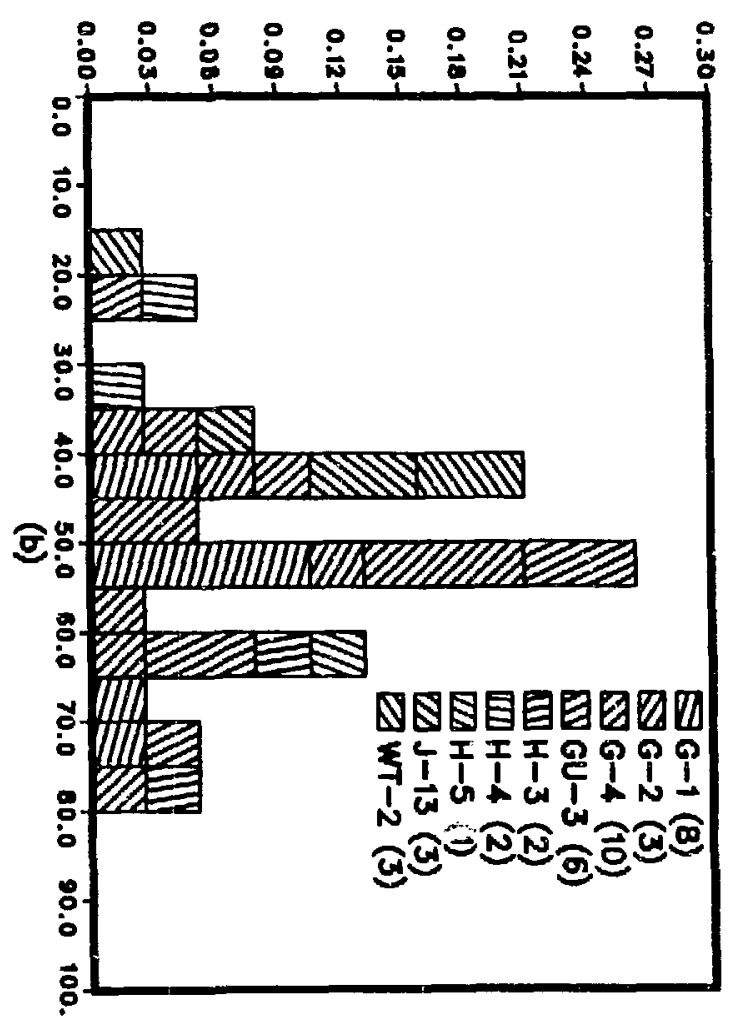


$x$

$$
x \times x
$$

$\times$

$\times \mathrm{CH} \ln 1$ and $\mathrm{CHn} 2$

- $\mathrm{CHn} 3$

aCFUn

由 Bottom of CFUn

+ CFMn1, CFMn2 and CFMn3

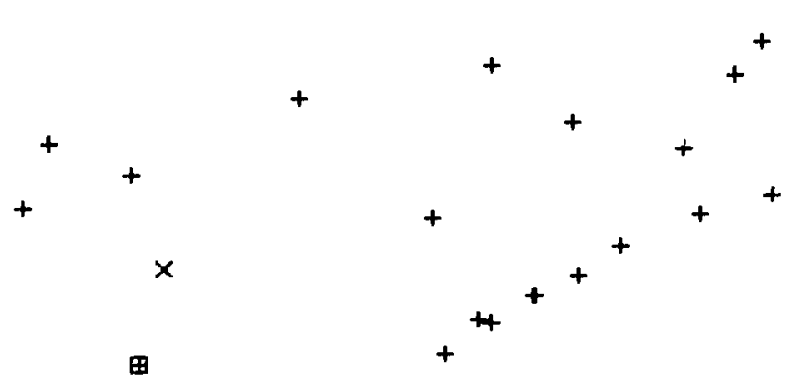

:
00

口

Figure 10. Projection of XRD data onto a plane in which the three major zeolitized units are well separated. There is considerable overlap among the three units, even in this optimal projection. CHn3 samples and samples from the bottom of CFUn are particularly likely to fall into the area of overlap with the unit below. 
However, the number of samples that might be reclassified in a different grouping is small, and in this section we will consider the major zeolitized intervals defined by Ortiz et al. as the basic units:

--CHn (zeolitized), defined in Table 1 of Ortiz et al. as "Calico Hills and Lower Paintbrush nonwelded unit", but including as well the upper partially welded ash flows of the Prow Pass Member of the Crater Flat Tutf (CHn3);

--CFUn, the "upper Crater Flat nonwelded unit", including nonwelded, partially welded and bedded, reworked portions of both the lower Prow Pass and the upper Bullfrog Members of the Crater Flat Tuff; and

- CFMn, the three mide Crater Flat nonwelded units, which include ashflows from both the lower Bulifrog and the upper Tram Members of the Crater Flat Tuff.

\section{A. CHn (zeolitized).}

Lateral variation in the mineralogy of these units can be ascribed primarily to USW G-2, to the north of the Exploratory Block, which is high in silica polymorphs, particularly cristobalite. The division of zeolites between clinoptilolite and mordenite is also somewhat different than in the other holes, but this difference appears to be part of a trend from north to south of decreasing mordenite and increasing clinoptilolite (see Fig. 11).

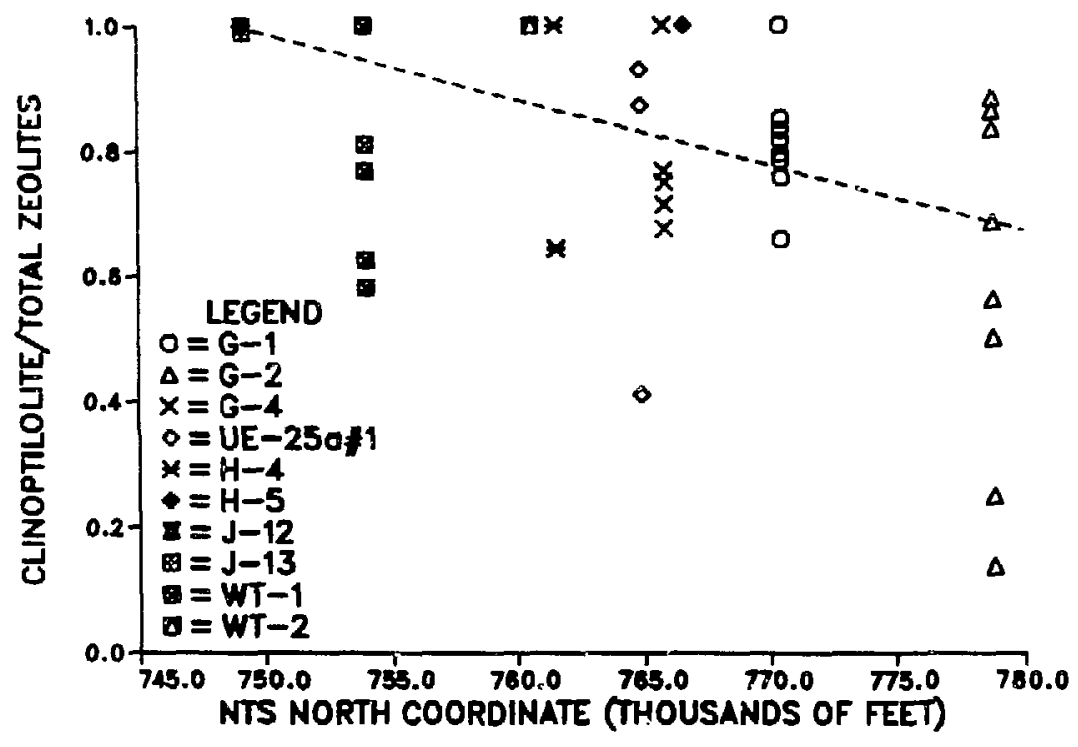

Fioure 11. Proportion of total zeolitization composed of clinoptilolite in samples from $\mathrm{CHn}$. The dashed line is the model for $E(F(y))$ of $E q .(1)$. 
Total zeolitization in G-2 is comparable to other drill holes. Samples from the bottom of $\mathrm{CHnl}$ in $\mathrm{G}-2$ (just above a significant low-angle fault, according to Scott and Bonk, 1984) are particularly discrepant, and visible as outliers in plots such as Fig. 10.

In addition, the two WT holes appear to have less zeolitization and more alkali-feldspar than average. (This difference may be owing to contamination by fragments from the overlying devitrified units as the drilling fluid carried the cuttings up from the drilling zone.) Moreover, in these two holes, as in J-12 and J-13, the contacts between the CHn units and the overlying Tcpopah Spring Member of the Paintbrush Tuff and the welded Prow Pass unit below are not always estimable from the sparsely and randomly selected XRD data. This means that an accurate measureinent of the "relative depth" of a sample in CHn, the linear function of true depth that is zero at the top of CHn1 and one at the bottom of $\mathrm{CHn}_{3}$, is not available for samples from these holes. Depth is a significant factor in accounting for tutal zeolitization and alkali-feldspar abundance in the XRD samples, as illustrated by Figs. 12 and 13 .

The models of Table 2 are constructed without the four holes that were not considered by ortiz et al. The several outliers mentioned in earlier parts of this report and three samples from the bottom of CHnl in USW G-2 are also omitted. In addition, all $G-2$ samples were omitted in estimating parameters for the distribution of total silica polymorphs (although not cristobalite and quartz individually). In general samples from $\mathrm{J}-12$ and $\mathrm{J}-13$ conform well to these models, but the WT holes are significantly different as noted in the footnote to Table 2 .

All of the models in Table 2 are constructed beginning with a model for the mean (possibly depth dependent; " $D$ " in Table 2 denotes "relative depth" in $\mathrm{CHn}$ as defined above) and standard deviation of the square root of the abundance (in per cent) of the given mineral. From these models the mean and standard deviation of the abundance is computed (see Appendix D), and the parameters of a beta distributicn with matching first and second moments are derived (details in Appendix D). Some of the models are illustrated in Figs. 14 through 16, superimposed on histograms of the data. It should be emphasized at this point that these are preliminary, univariate models serving primarily to indicate the extent to which observed variability in the data is unaccounted for by detectable trends. 


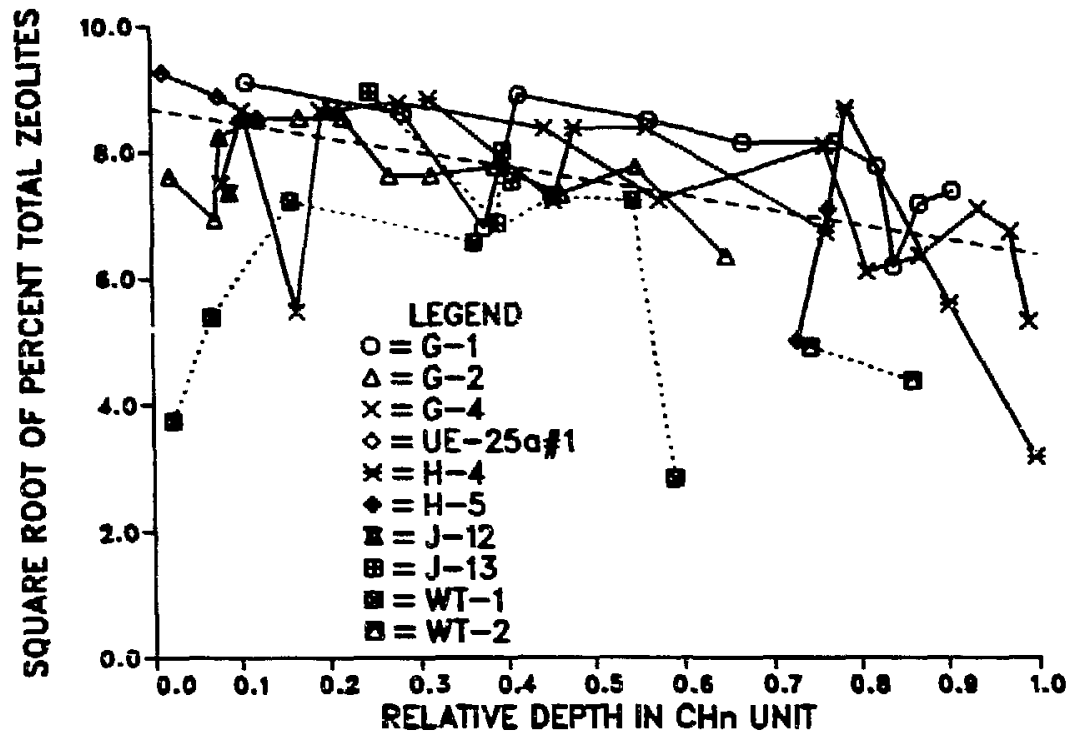

Figure 12. Zeolitization of samples from CHn, plotted as a function of the depth in CHn, measured as a fraction of the distance between the top and the bottom of the unit. The dashed line is the linear model proposed in Table 2.

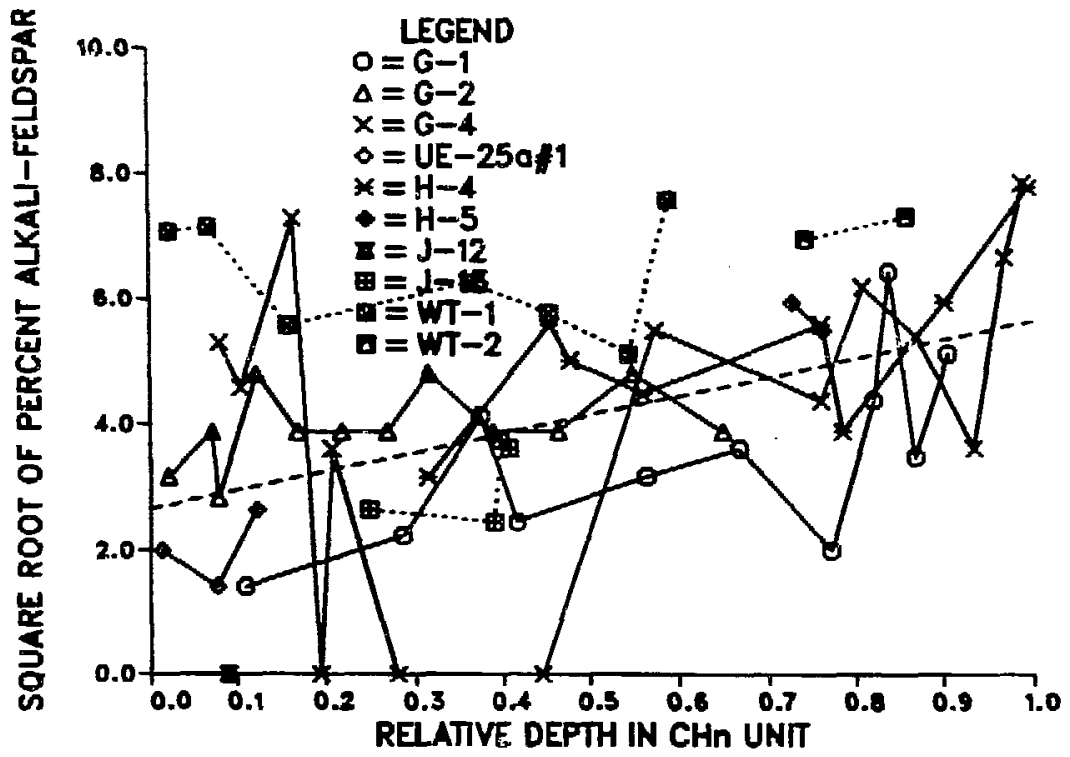

Figure 13. Abundance of alkali-feldspar in samples from $\mathrm{CHn}$, plotted as a function of depth in Chn. 
TABLE 2.

MODELS FOR ABUNDANCE OF MINERALS IN CHn

$\frac{\text { SQUARE ROCT }}{\text { MEAN S.D }}$

TOTAL ZEOLITES ${ }^{1}$

$\frac{\text { PERCENTAGE }}{\text { MEAN S.D. }}$

BETA DISTRIBUTION

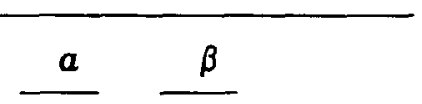

$\begin{array}{lllll}68.642 & 16.837 & 4.53 & 2.07 & (D=0.2) \\ 57.591 & 15.411 & 5.35 & 3.94 & (D=0.5) \\ 47.526 & 13.986 & 5.58 & 6.17 & (D=0.8)\end{array}$

CRISTOBALITE

3.48

1.18

13.503

8.446

$2.08 \quad 13.30$

QUARTZ

2.27

1.20

6.593

5.816

$1.13 \quad 16.07$

SILICA POLYMORPHS

4.07

1.03

17.626

8.517

$3.35 \quad 15.66$

ALKALI-FELDSPAR ${ }^{2}$

$2.66+2.95 * D$

1.59

13.09

19.626

27.729

10.936

1.11

1.47

1.80

7.40

6.02

4.69

$(D=0.2)$

16.359

$0.60 \quad 24.28$

SMECTITE

1.06

1.13

2.403

3.010

$0.820 \quad 1.066$

$0.58 \quad 69.99$

MICA

0.57

0.71

Notes: 1. Zeolitization is lower in USW WT-1 and WT-2.

2. Alkali-feldspars are more abundant in USW WT-1 and WT-2.

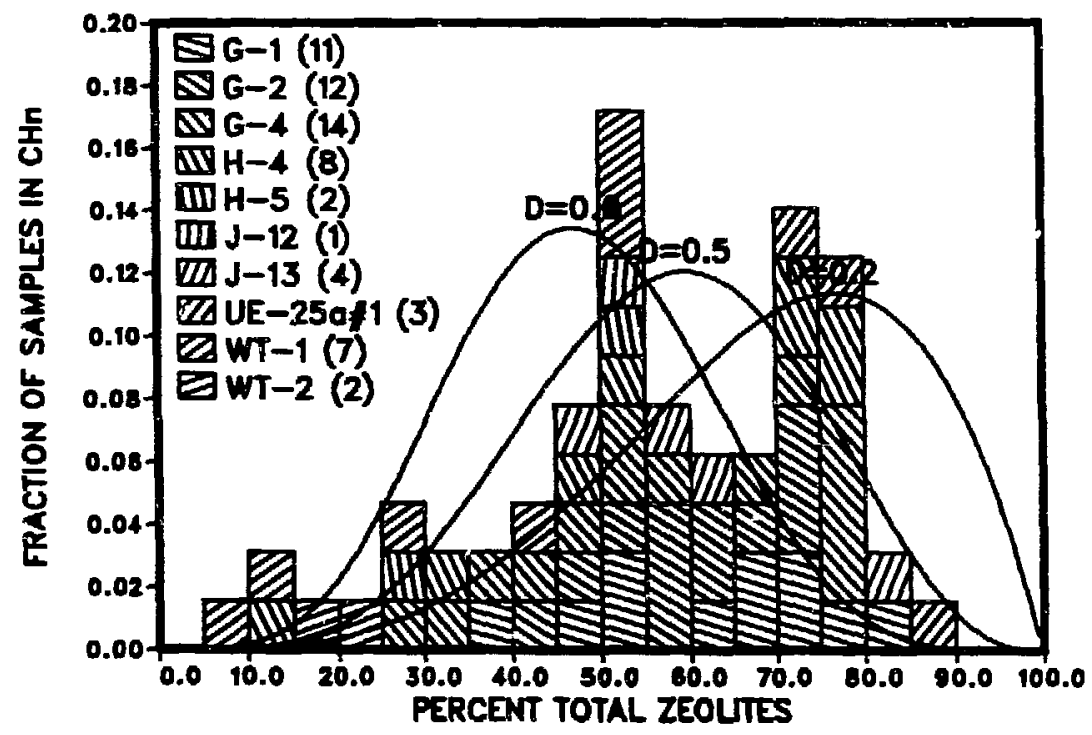

Figure 14. Models for zeolitization of the CHn unit at different depths, superimposed on a histogram of the samples from this unit. Samples with zero weight have been excluded from the histogram; compare with Figure 9a. 


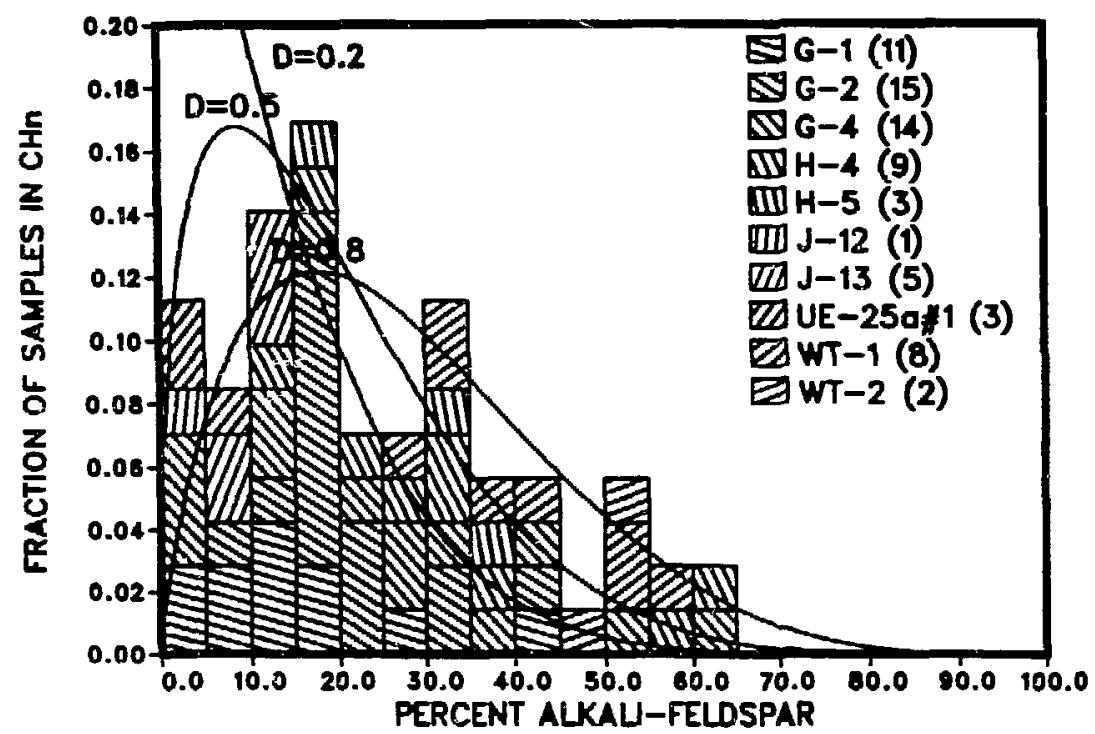

Figure 15. Models for alkali-feldspar abundance in the CHn unit at different depths, superimposed on a histogram of the samples from this unit.

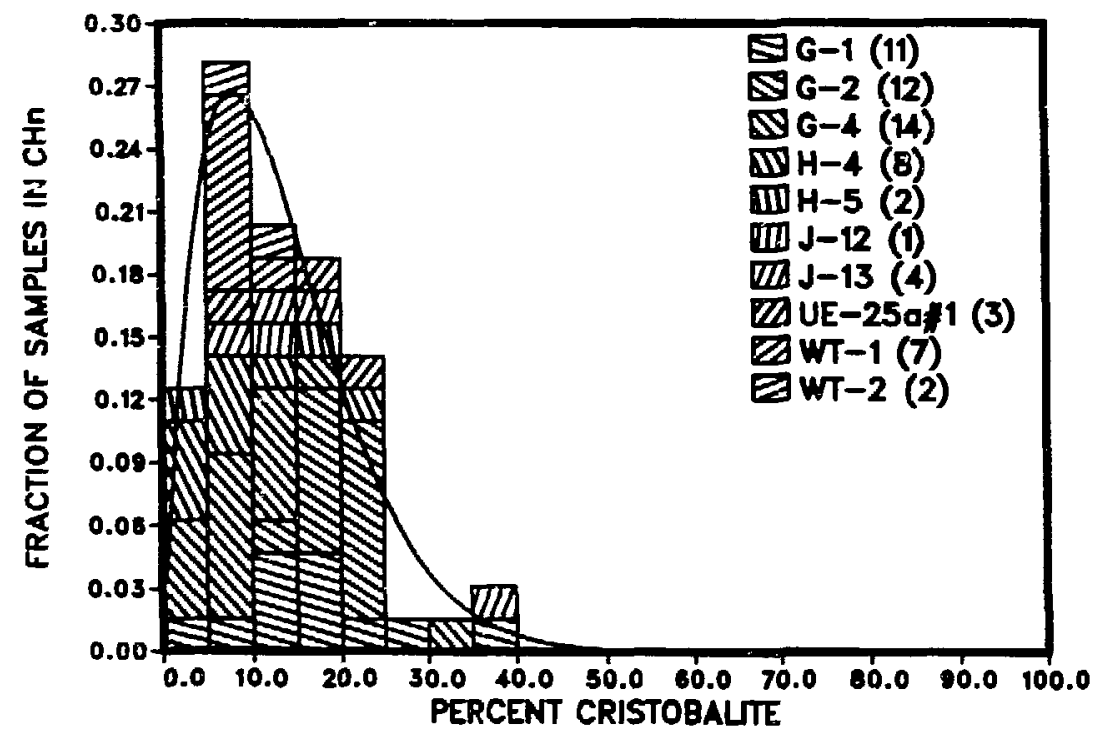

Figure 16. Model for cristobalite abundance in the CHn unit, superimposed on a histogram of the samples from this unit. 
Near the Exploration Biock, the change in zeolite composition from south to north can be approximated by a linear trend (see Fig. 11). Thus the model proposed for clinoptilolite is of the form $F(y) \times Z(D)$, where $F(y)$ is the fraction of the total zeolitization made up of clinoptilolite (a function of north-south position $y$ ), which is stochastically independent of the total zeolite abundance $Z(D)$ (the function of depth given in Table 2 ). $F(y)$ is modeled as a random variable with expected value:

$$
E(F(y))=0.830-0.01052(y-765)
$$

(where $y$ is the Nevada State north coordinate divided by 1000 ; the value of $y$ at USW G-4 is 765.807), and variance

$$
V(F(y))=0.0375 \text {. }
$$

Similarly, a model for the mordenite is of the form $(1-F(y)) \times Z(D)$. Between USW GU-3 and G-2, $E(F(y))$ is greater than zero and less than one. At J-12 and $\mathrm{J}-13$, the zeolitization is virtually $100 \%$ clinoptilolite. Some typical parameters are given in Table 3.

TABLE 3.

\begin{tabular}{|c|c|c|c|c|c|}
\hline & \multirow{2}{*}{$\begin{array}{c}\text { NTS NORTH } \\
\text { COORDINATE (FEET) }\end{array}$} & \multicolumn{2}{|c|}{ PERCENTAGE } & \multicolumn{2}{|c|}{ BETA OISTRIBUTIO } \\
\hline & & MEAN & S.D. & $a$ & $\beta$ \\
\hline CLINOPTILOLITE: & $\begin{array}{l}756,542(\mathrm{H}-3) \\
765,807(\mathrm{G}-4) \\
778,824(\mathrm{G}-2)\end{array}$ & $\begin{array}{l}52.92 \\
47.31 \\
39.43\end{array}$ & $\begin{array}{l}18.27 \\
17.13 \\
15.64\end{array}$ & $\begin{array}{l}3.42 \\
3.54 \\
3.46\end{array}$ & $\begin{array}{l}3.04 \\
3.95 \\
5.31\end{array}$ \\
\hline MORDENI TE: & $\begin{array}{l}756,542(\mathrm{H}-3) \\
765,807(\mathrm{G}-4) \\
778,824(\mathrm{G}-2)\end{array}$ & $\begin{array}{r}4.67 \\
10.28 \\
18.17\end{array}$ & $\begin{array}{l}11.61 \\
11.87 \\
12.53\end{array}$ & $\begin{array}{l}0.11 \\
0.57 \\
1.54\end{array}$ & $\begin{array}{l}2.19 \\
4.98 \\
6.94\end{array}$ \\
\hline
\end{tabular}

MODELS FOR CLINOPTILOLITE/MORDENITE DISTRIBUTION IN CHn AT D=0.5 
CFUn.

Among the nine drill holes with samples in this unit, J-13 stands out both because the zeolitization in the three J-13 samples (which come from within a few feet of each other) consists entirely of analcime and because the J-13 samples have higher than average quartz abundance (and total silica polymorphs). The remaining holes with samples in this unit, all near the Exploration Block, are relatively uniform, except for a change in zeolite composition ranging from $100 \%$ clinoptilolite in the south (USW GU-3 and H-3) down to an average $40 \%$ clinoptilolite at the north end (USW G-2), with the balance being composed of mordenite (and analcime in one G-2 sample). See Fig. 17.

As in $\mathrm{CHn}$, depth is a factor explaining much of the variability in total zeolitization (Fig. 18) and in alkali-feldsoar abundance, but no lateral trends are observed in either. Again, a model that is linear in relative depth (in CFUn) is proposed for alkali-feldspar abundance and for total zeolitization (Table 4). For clinoptilolite a model of the form $F(y) \times Z(D)$ is suggested, where $F(y)$ is approximated by a random variable with expected

TABLE 4.

MODELS FOR ABUNDANCE OF MINERALS IN CFUn

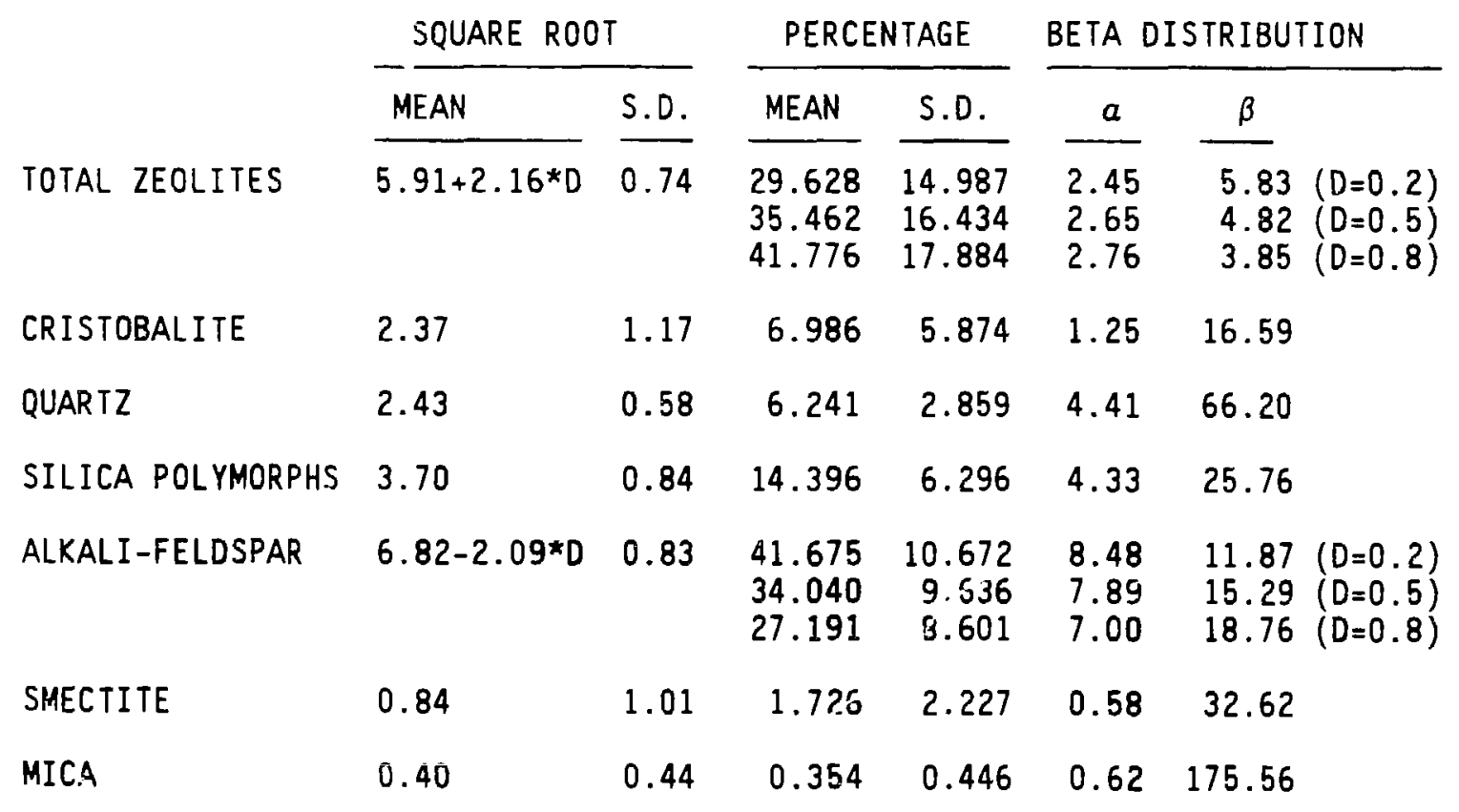




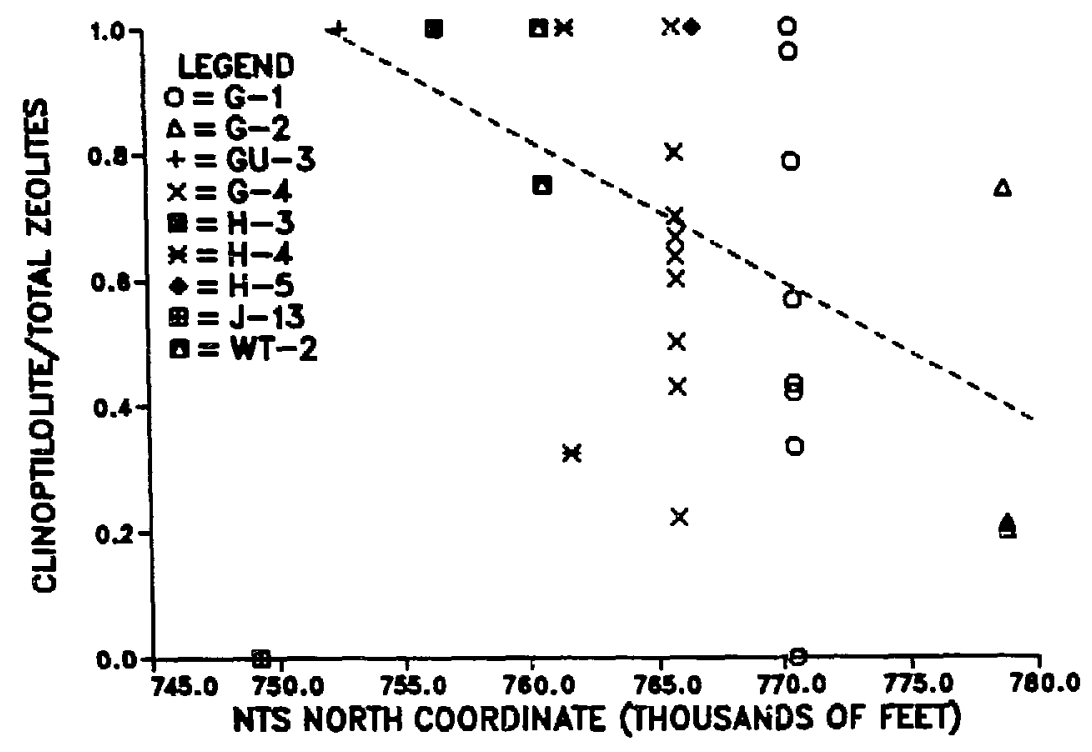

Figure 17. Proportion of total zeolitization composed of clinoptilolite in samples from CFUn. The dashed line is the model for $E(F(y))$ of Eq. 2 .

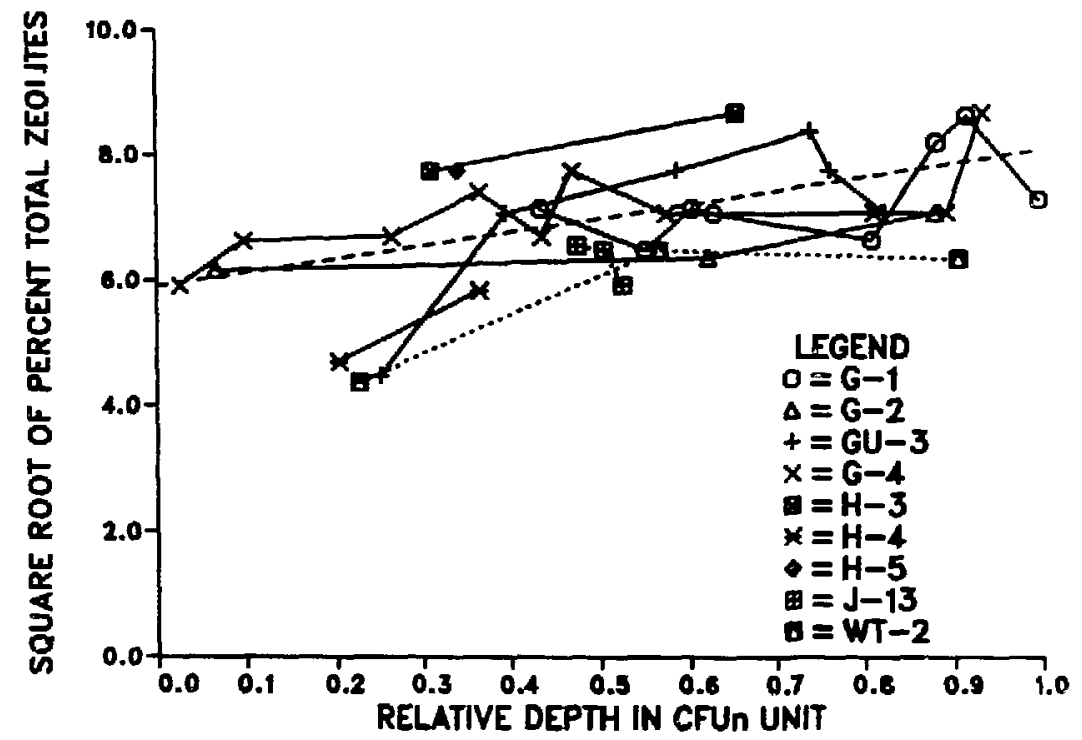

Figure 18. Zeolitization of samples from CFUn, plotted as a function of the depth in CFUn, measured as a fraction of the distance between the top and the bottom of the unit. The dashed line is the model proposed in Table 4. 
value:

$$
E(F(y))=0.710-0.02264(y-765)
$$

(where $y$ is the Nevada State north coordinate divided by 1000 , as before) and variance

$$
V(F(y))=0.0415
$$

(see Fig. 17). Between USW GU-3 and $G-2, E(F(y))$ is greater than zero and less than one; the model clearly does not apply at J-13. Some typical parameters are given in Table 5.

\section{CFMn.}

The seven holes that contain samples from the lowest zeolitized interval considered, the middle Crater Flat nonwelded unit, are divided into two very different groups. Three holes to the north and east of the Exploration Block, J-13, UE-25b\#1H and USW G-2, have little clinoptilolite, lower overall zeolitization, no cristobalite, and more quartz than three holes within the Exploration Block, namely USW G-1, GU-3 and H-3. USW G-4 resembles holes in the first group with respect to the distribution of silica polymorphs, but because it has slightly more clinoptilolite and several samples very high in mordenite (more than 60\%), USW G-4 has higher overall zeolitization than other

TABLE 5 .

\begin{tabular}{|c|c|c|c|c|c|}
\hline & \multirow{2}{*}{$\begin{array}{c}\text { NTS NORTH } \\
\text { COORDINATE (FEET) } \\
\end{array}$} & \multicolumn{2}{|c|}{ PERCENTAGE } & \multicolumn{2}{|c|}{ BETA DISTRIBUTIO } \\
\hline & & MEAN & S.D. & $a$ & $\beta$ \\
\hline CLINOPTILOLITE: & $\begin{array}{l}756,542(\mathrm{H}-3) \\
765,807(\mathrm{G}-4) \\
778,824(\mathrm{G}-2)\end{array}$ & $\begin{array}{l}44.54 \\
34.18 \\
19.62\end{array}$ & $\begin{array}{l}13.90 \\
12.54 \\
11.08\end{array}$ & $\begin{array}{l}5.25 \\
4.55 \\
2.32\end{array}$ & $\begin{array}{l}6.54 \\
8.76 \\
9.52\end{array}$ \\
\hline MORDENI TE : & $\begin{array}{l}756,542(\mathrm{H}-3) \\
765,807(\mathrm{G}-4) \\
778,824(\mathrm{G}-2)\end{array}$ & $\begin{array}{r}4.87 \\
15.23 \\
29.79\end{array}$ & $\begin{array}{l}10.34 \\
10.77 \\
12.04\end{array}$ & $\begin{array}{l}0.16 \\
1.54 \\
4.00\end{array}$ & $\begin{array}{l}3.17 \\
8.59 \\
9.43\end{array}$ \\
\hline
\end{tabular}

MODELS FOR CLINOPTILOLITE/MORDENITE DISTRIBUTION IN CFUn AT $D=0.5$ 
samples in the "northeast" group. Analcime appears in most G-2 samples, and the zeolitization of $\mathrm{J}-13$ is entirely an: lcime.

This split is clearly seen, for example, in "box" plots of the CFMn samples by drill hole in Figs. 19 and 20: in these figures the boxes out line the central $50 \%$ of the distribution in each hole, with tails extending to the minimum and maximum observations, and the slightly longer vertical line in each box shows the median observation. Apart from this split, no significant vertical or lateral trends in the mineralization of this unit are noted. Thus in Table 6 one or two models are proposed for each mineral. Where two are suggested, the "NE" model applies north and east of a line running south of USW G-2 but north of G-1, thence southward near but west of USW G-4, and east of USW H-3 and GU-3. The "SW" model applies south and west of this line. As no samples at this depth are available from USW H-4, WT-1 or WT-2, it is not possible to describe this apparent split in mineralization in more detail. Models for clinoptilolite and quartz are illustrated in Figs. 21 and 22.

TABLE 6 .

MODELS FOR ABUNDANCE OF MINERALS IN CFMn

\begin{tabular}{|c|c|c|c|c|c|}
\hline & \multicolumn{2}{|c|}{ PERCENTAGE } & \multicolumn{2}{|c|}{ BETA DISTRIBUTION } & \\
\hline & MEAN & S.D. & $a$ & $\beta$ & \\
\hline CLINOPTILOLITE & $\begin{array}{r}4.182 \\
36.185\end{array}$ & $\begin{array}{r}5.392 \\
13.743\end{array}$ & $\begin{array}{l}0.53 \\
4.06\end{array}$ & $\begin{array}{r}12.25 \\
7.16\end{array}$ & $\begin{array}{l}(\mathrm{NE}) \\
(\mathrm{SW})\end{array}$ \\
\hline MORDENI TE & 17.391 & 19.115 & 0.51 & 2.42 & \\
\hline TOTAL ZEOLITES & $\begin{array}{l}30.445 \\
58.306\end{array}$ & $\begin{array}{l}18.484 \\
21.697\end{array}$ & $\begin{array}{l}1.58 \\
2.08\end{array}$ & $\begin{array}{l}3.62 \\
2.23\end{array}$ & $\begin{array}{l}(\mathrm{NE}) \\
(\mathrm{SW})\end{array}$ \\
\hline CRISTOBAL I TE & $\begin{array}{l}0.000 \\
2.227\end{array}$ & $\begin{array}{l}0.000 \\
2.920\end{array}$ & 0.55 & 24.00 & $\begin{array}{l}(\mathrm{NE}) \\
(\mathrm{SW})\end{array}$ \\
\hline QUARTZ & $\begin{array}{r}25.978 \\
7.932\end{array}$ & $\begin{array}{l}7.757 \\
6.119\end{array}$ & $\begin{array}{l}8.04 \\
1.47\end{array}$ & $\begin{array}{l}22.91 \\
17.04\end{array}$ & $\begin{array}{l}(\mathrm{NE}) \\
(\mathrm{SW})\end{array}$ \\
\hline SILICA POL YMORPHS & $\begin{array}{l}25.978 \\
12.42\end{array}$ & $\begin{array}{l}7.76 \\
7.21\end{array}$ & $\begin{array}{l}8.04 \\
2.48\end{array}$ & $\begin{array}{l}22.91 \\
17.47\end{array}$ & $\begin{array}{l}(\mathrm{NE}) \\
(\mathrm{SW})\end{array}$ \\
\hline ALK,ALI - FELDSPAR & 34.29 & 12.60 & 4.52 & 8.67 & \\
\hline SMECTITE & 6.88 & 8.19 & 0.59 & 7.96 & \\
\hline MICA & 3.51 & 3.52 & 0.98 & 27.03 & \\
\hline
\end{tabular}




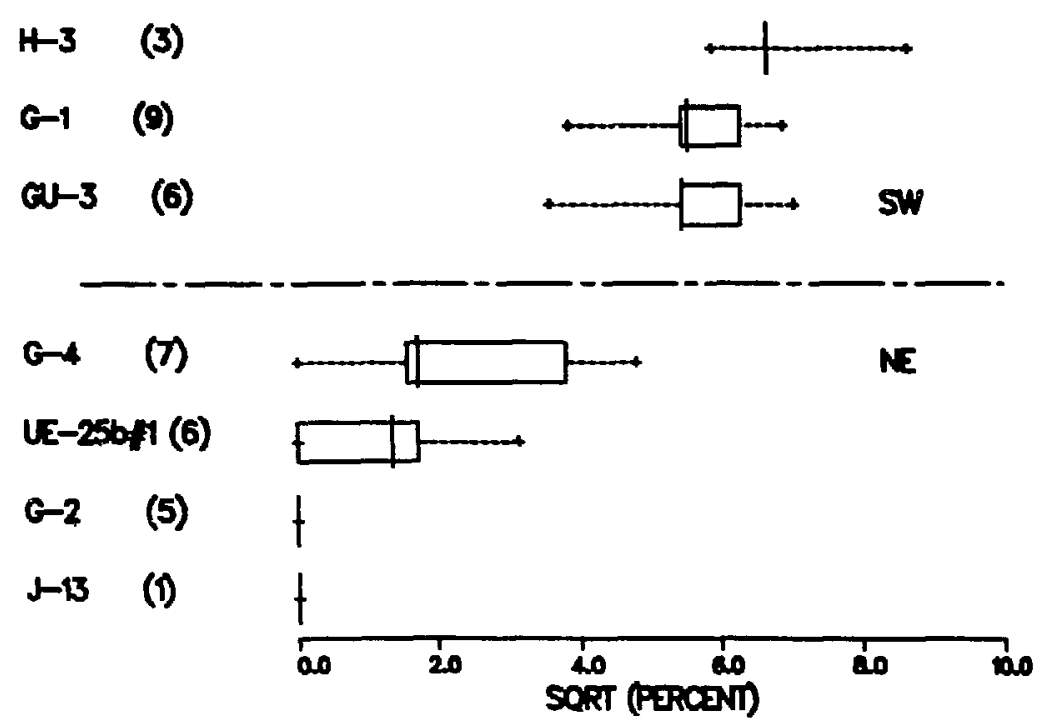

Figure 19. Distribution of clinoptilolite in samples from CFMn by drill hole. The boxes delineate the central $50 \%$ of the distribution in each hole, with tails extending to the smallest and largest observations.

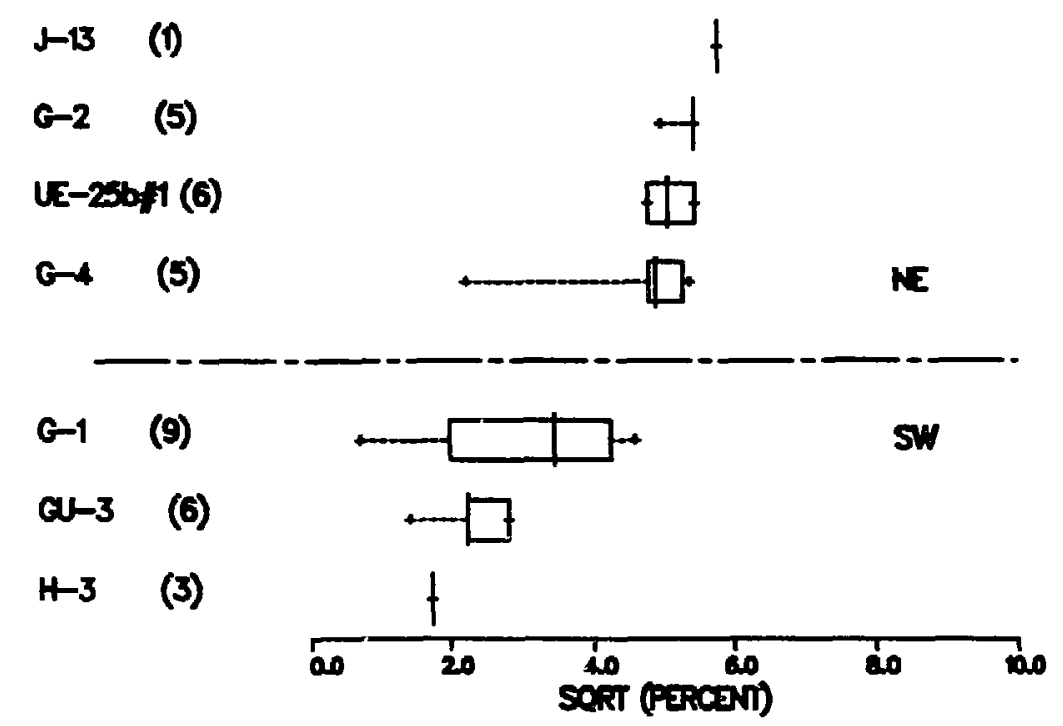

Figure 20. Distribution of quartz in samples from CFMn by drill hole. 


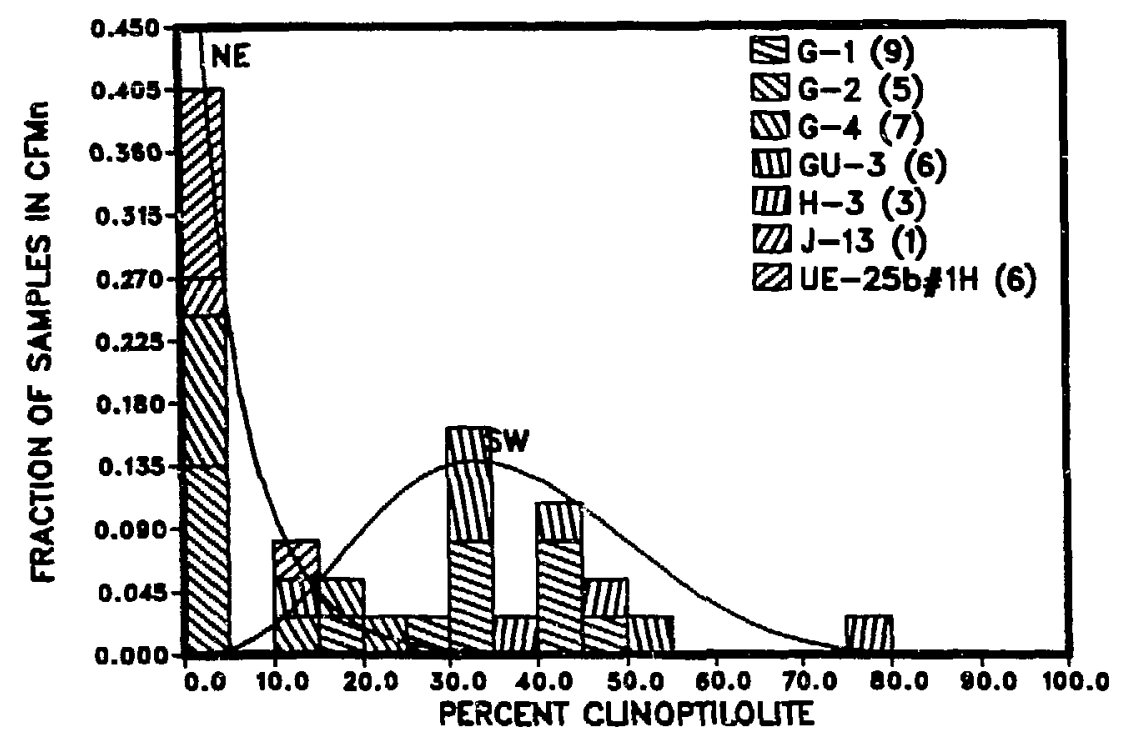

Figure 21. Models for clinoptilolite abundance in the CFMn units for the "north-east" holes J-13, UE-25b\#1H, USW G-2 and G-4, and the "south-west" holes USW GU-3, H-3 and G-4, superimposed on a histogram of the samples from these units.

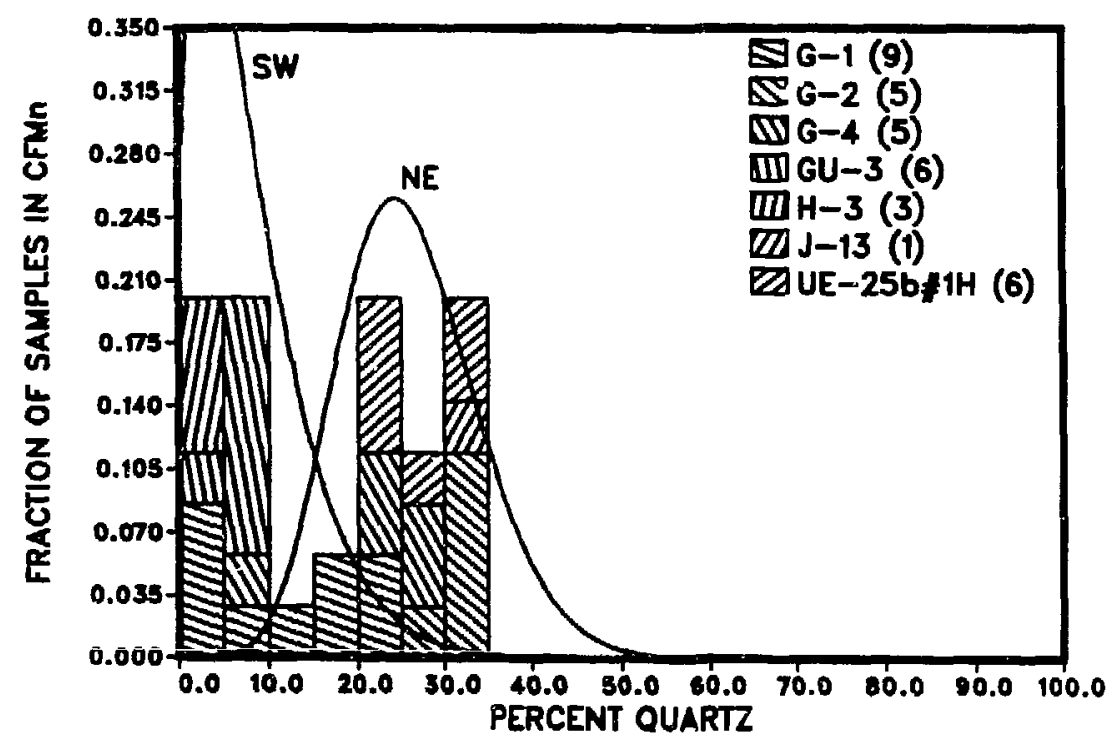

Figure 22. Models for quartz abundance in the CFMn units for the "north-east" and "south-west" holes, super imposed on a histogram of the samples from these units. 


\section{SUMMARY}

A few systematic lateral trends were noted in the preceding section, primarily in the types of zeolites w:thin zeolitized units. On the whole, however, the variability in mineral distribution among drill holes does not appear to be significantly greater than the variability within holes. The exceptions to this statement are 1) the geographic split between two groups of holes in the lowest CFMn units, with high clinoptilolite and low quartz to the southwest and low clinoptilolite and high quartz to the northeast, and 2) instances in which holes that are well outside the Exploration Block (i.e., 3-12, J-13 and USW G-2) appear to be different from the remaining holes. The CFMn split can be traced with some accuracy at the northern end of Yucca Mountain, but its continuation to the south can not be mapped owing to the absence of samples at this depth in the existing holes near the southeast boundary of the Exploration Block. The frequent appearance of holes removed from the Exploration Block as "outliers" with respect to the bulk of the data suggests that the models proposed in the preceding section are not applicable beyond its boundaries. In particular, if the northward extension of the potential repository is contemplated, additional sampling of this region is clearly required.

Earlier in the report, additional "anomalous" observations were noted, but these occurred generally in the nonwelded tuffs above the potential repository horizon, and improved knowledge of the mineralization of these units will not influence modeling of retardation along flow paths below the repository. Better characterization of the thin, smectite-bearing layer at the top of TSW3, however, would be desirable.

The model distributions proposed in the preceding section are generally broad, even after accounting for trends with depth and for some lateral effects where these are sufficiently systematic to be modeled. For transport modeling, the use of stochastic simulation, rather than a deterministic, possibly depth- and coordinate-dependent function. would be appropriate. of course, the models given here are only for the marginal distributions of the minerals, and a complete stochastic model would have to take into account the multivariate structure and the constraint that the percentages of the minerals at any point must add up to one hundred. 
ACKNOWLEDGEMENTS

The author thanks David T. Vaniman, David L. Bish and Richard J. Beckman for reviewing this manuscript. David Vaniman adapted Fig. 2 from Ortiz et al. (1985). 
SUMMARY TABLE OF XRD DATA BY FUNCTIONAL UNIT

FROM DRILL HOLES AND STRATA CONSIDERED BY ORTIZ ET AL.

\begin{tabular}{|c|c|c|c|c|c|}
\hline Unit & $\begin{array}{l}\text { Mineral- } \\
\text { ization }\end{array}$ & Hole & $\begin{array}{l}\text { Samp le } \\
\text { Type }\end{array}$ & $\begin{array}{c}\text { Number of } \\
\text { Samples }\end{array}$ & Exceptions \\
\hline TCW & $d$ & $\begin{array}{l}\text { USW G-2 } \\
\text { USW GU-3 } \\
\text { USW G-4 } \\
\text { UE- } 25 \text { a } 1 \\
\text { USW H-5 }\end{array}$ & $\begin{array}{l}\text { Core } \\
\text { Core } \\
\text { Core } \\
\text { Core } \\
\text { Cuttings }\end{array}$ & $\begin{array}{l}3 \\
9 \\
3 \\
3 \\
2\end{array}$ & $\begin{array}{l}2 \\
2\end{array}$ \\
\hline PTn & $v$ & $\begin{array}{l}\text { USW G-2 } \\
\text { USW GU-3 } \\
\text { USW G-4 } \\
\text { UE- } 25 a \# 1 \\
\text { USW H-5 }\end{array}$ & $\begin{array}{l}\text { Core } \\
\text { Core } \\
\text { Core } \\
\text { Core } \\
\text { Cuttings }\end{array}$ & $\begin{array}{r}17 \\
7 \\
6 \\
3 \\
2\end{array}$ & $\begin{array}{l}2 \\
2\end{array}$ \\
\hline TSWI & $d$ & $\begin{array}{l}\text { USW } G-1 \\
\text { USW } G-2 \\
\text { USW GU-3 } \\
\text { USW G-4 } \\
\text { UE-25a\#1 }\end{array}$ & $\begin{array}{l}\text { Core } \\
\text { Core } \\
\text { Core } \\
\text { Core } \\
\text { Core }\end{array}$ & $\begin{array}{r}13 \\
16 \\
8 \\
10 \\
13\end{array}$ & 2 \\
\hline$T S w 2^{2}$ & $d$ & $\begin{array}{l}\text { USW G-1 } \\
\text { USW G-2 } \\
\text { USW GU-3 } \\
\text { USW G-4 } \\
\text { UE-25a\#1 } \\
\text { USW H-3 } \\
\text { USW H-4 } \\
\text { USW H-5 } \\
\text { USW H-6 }\end{array}$ & $\begin{array}{l}\text { Core } \\
\text { Core } \\
\text { Core } \\
\text { Core } \\
\text { Core } \\
\text { Cuttings } \\
\text { Cuttings } \\
\text { Cuttings } \\
\text { Core }\end{array}$ & $\begin{array}{r}9 \\
2 \\
11 \\
13 \\
3 \\
12 \\
10 \\
13 \\
4\end{array}$ & $\begin{array}{l}2 \\
2 \\
2 \\
2 \\
1,4\end{array}$ \\
\hline TSw3 & $v$ & $\begin{array}{l}\text { USW G-1 } \\
\text { USW G-2 } \\
\text { USW GU-3 } \\
\text { USW G-4 } \\
\text { UE-25a\#1 } \\
\text { USW H-4 } \\
\text { USW H-5 }\end{array}$ & $\begin{array}{l}\text { Core } \\
\text { Core } \\
\text { Core } \\
\text { Core } \\
\text { Core } \\
\text { Cuttings } \\
\text { Cuttings }\end{array}$ & $\begin{array}{l}2 \\
2 \\
2 \\
6 \\
2 \\
1 \\
2\end{array}$ & $\begin{array}{l}2 \\
2 \\
2\end{array}$ \\
\hline
\end{tabular}

(cont inued on next page) 


\begin{tabular}{|c|c|c|c|c|c|}
\hline Unit & $\begin{array}{l}\text { Mineral- } \\
\text { ization }\end{array}$ & Hole & $\begin{array}{l}\text { Sample } \\
\text { Type }\end{array}$ & $\begin{array}{c}\text { Number of } \\
\text { Samp les }\end{array}$ & Exceptions \\
\hline \multirow[t]{2}{*}{$\mathrm{CHn} 1$} & $v$ & $\begin{array}{l}\text { USW } G-1 \\
\text { USW GU-3 } \\
\text { USW H-3 } \\
\text { USW } H-4 \\
\text { USW H-5 } \\
\text { USH H-6 }\end{array}$ & $\begin{array}{l}\text { Core } \\
\text { Core } \\
\text { Cuttings } \\
\text { Sidewall } \\
\text { Cuttings } \\
\text { Sidewal } \\
\text { Cuttings } \\
\text { Core }\end{array}$ & $\begin{array}{r}2 \\
12 \\
2 \\
1 \\
1 \\
5 \\
2 \\
4\end{array}$ & $\begin{array}{l}2 \\
2 \\
2 \\
2 \\
2 \\
1,4\end{array}$ \\
\hline & $z$ & $\begin{array}{l}\text { USW G-1 } \\
\text { USW G-2 } \\
\text { USW G-4 } \\
\text { UE-25a\#1 } \\
\text { USW H-4 }\end{array}$ & $\begin{array}{l}\text { Core } \\
\text { Core } \\
\text { Core } \\
\text { Core } \\
\text { Sidewall } \\
\text { Cuttings }\end{array}$ & $\begin{array}{r}6 \\
15 \\
10 \\
3 \\
3 \\
4\end{array}$ & $\begin{array}{l}2 \\
2 \\
2\end{array}$ \\
\hline $\mathrm{Ch}_{1,2}$ & $\begin{array}{l}v \\
z\end{array}$ & $\begin{array}{l}\text { USW GU-3 } \\
\text { USW G-1 } \\
\text { USW G-4 } \\
\text { USW H-4 } \\
\text { USW H-5 }\end{array}$ & $\begin{array}{l}\text { Core } \\
\text { Core } \\
\text { Core } \\
\text { Cuttings } \\
\text { Sidewall } \\
\text { Cuttings }\end{array}$ & $\begin{array}{l}2 \\
4 \\
2 \\
1 \\
1 \\
1\end{array}$ & $\begin{array}{l}2 \\
2 \\
2 \\
2\end{array}$ \\
\hline $\mathrm{CHn} 3$ & z & $\begin{array}{l}\text { USW GU-3 } \\
\text { USW } H-3 \\
\text { USW } H-6 \\
\text { USW } G-1 \\
\text { USW G-4 } \\
\text { USW } H-4 \\
\text { USW } H-5\end{array}$ & $\begin{array}{l}\text { Core } \\
\text { Sidewa } 11 \\
\text { Core } \\
\text { Core } \\
\text { Core } \\
\text { Cuttings } \\
\text { Sidewa } 11\end{array}$ & $\begin{array}{l}2 \\
3 \\
1 \\
1 \\
3 \\
1 \\
1\end{array}$ & $\begin{array}{l}2 \\
1,4 \\
2 \\
2 \\
2\end{array}$ \\
\hline PPw & $\delta$ & $\begin{array}{l}\text { USW G-1 } \\
\text { USW G-2 } \\
\text { USW GU-3 } \\
\text { USW G-4 } \\
\text { UE- } 25 a \# 1 \\
\text { USW } H-4 \\
\text { USW } H-6\end{array}$ & $\begin{array}{l}\text { Core } \\
\text { Core } \\
\text { Core } \\
\text { Core } \\
\text { Core } \\
\text { Sidewall } \\
\text { Cuttings } \\
\text { Core }\end{array}$ & $\begin{array}{l}1 \\
7 \\
5 \\
5 \\
1 \\
1 \\
1 \\
2\end{array}$ & $\begin{array}{l}2 \\
2 \\
2 \\
1,4\end{array}$ \\
\hline CFUn & 2 & $\begin{array}{l}\text { USW } G-1 \\
\text { USW G-2 } \\
\text { USW } E U-3 \\
\text { USW } G-4 \\
\text { USW } H-3 \\
\text { USW } H-4 \\
\text { USW } H-5\end{array}$ & $\begin{array}{l}\text { Core } \\
\text { Core } \\
\text { Core } \\
\text { Core } \\
\text { Sidawall } \\
\text { Cuttings } \\
\text { Cuttings }\end{array}$ & $\begin{array}{r}8 \\
3 \\
6 \\
10 \\
2 \\
3 \\
1\end{array}$ & $\begin{array}{l}2 \\
2 \\
2 \\
2\end{array}$ \\
\hline
\end{tabular}




\begin{tabular}{|c|c|c|c|c|c|}
\hline Unit & $\begin{array}{l}\text { Mineral- } \\
\text { ization }\end{array}$ & Hole & $\begin{array}{l}\text { Samp le } \\
\text { Type }\end{array}$ & $\begin{array}{c}\text { Number of } \\
\text { Samples }\end{array}$ & Exceptions \\
\hline$B F w$ & $d$ & $\begin{array}{l}\text { USW G-1 } \\
\text { USW G-2 } \\
\text { USW GU-3 } \\
\text { USW G-4 } \\
\text { UE - 25b\#1H } \\
\text { USW H-6 }\end{array}$ & $\begin{array}{l}\text { Core } \\
\text { Core } \\
\text { Core } \\
\text { Core } \\
\text { Core } \\
\text { Core }\end{array}$ & $\begin{array}{r}5 \\
5 \\
8 \\
12 \\
6 \\
2\end{array}$ & $\begin{array}{l}2 \\
3,4 \\
1,4\end{array}$ \\
\hline CFMn1 & $z$ & $\begin{array}{l}\text { USW G-1 } \\
\text { USW G-2 } \\
\text { USW GU-3 } \\
\text { USW G-4 } \\
\text { UE-25b\#1H } \\
\text { USW H-3 }\end{array}$ & $\begin{array}{l}\text { Core } \\
\text { Core } \\
\text { Core } \\
\text { Core } \\
\text { Core } \\
\text { Sidewall }\end{array}$ & $\begin{array}{l}3 \\
2 \\
3 \\
2 \\
2 \\
2\end{array}$ & $\begin{array}{l}2 \\
3,4 \\
2\end{array}$ \\
\hline CFMn2 & 2 & $\begin{array}{l}\text { USW G-1 } \\
\text { USW G-2 } \\
\text { USW GU-3 } \\
\text { USW G-4 } \\
\text { UE-25b\#1H }\end{array}$ & $\begin{array}{l}\text { Core } \\
\text { Core } \\
\text { Core } \\
\text { Core } \\
\text { Core }\end{array}$ & $\begin{array}{l}3 \\
2 \\
1 \\
1 \\
3\end{array}$ & $\begin{array}{l}2 \\
3,4\end{array}$ \\
\hline CFMn3 & $z$ & $\begin{array}{l}\text { USW G-1 } \\
\text { USW G-2 } \\
\text { USW G-4 } \\
\text { UE-25b\#1H }\end{array}$ & $\begin{array}{l}\text { Core } \\
\text { Core } \\
\text { Core } \\
\text { Core }\end{array}$ & $\begin{array}{l}3 \\
1 \\
4 \\
1\end{array}$ & $\begin{array}{l}2 \\
3,4\end{array}$ \\
\hline$T R w$ & $d$ & $\begin{array}{l}\text { USW G-1 } \\
\text { USW G-2 } \\
\text { UE-25b\#1H } \\
\text { USW H-6 }\end{array}$ & $\begin{array}{l}\text { Core } \\
\text { Core } \\
\text { Core } \\
\text { Core }\end{array}$ & $\begin{array}{r}14 \\
10 \\
19 \\
1\end{array}$ & $\begin{array}{l}3,4 \\
1,4\end{array}$ \\
\hline
\end{tabular}

'Coding for exceptions:

$1=$ Mordenite and calcite below detection 1 imits if present.

$2=$ Analcime, calcite and hematite below detection limits if present.

$3=$ Cristobalite below detection 7 imits if present.

$4=i r$ idymite and hematite below detection 7 imits if present.

2

TSWl and TSW2 were not distinguished in "H" holes by Ortiz et al. A11 samples from the devitrified Topopah Spring Member in these holes are categorized as TSW2. 
ASSIGNMENT OF SAMPLES FROM DRILL HOLES AND DEPTHS

NOT COVERED BY THE FUNCTIONAL STRATIGRAPHY OF ORTIZ ET AL. (1985)

\begin{tabular}{|c|c|c|c|}
\hline $\begin{array}{l}\text { Drill } \\
\text { Hole }\end{array}$ & Depth & $\begin{array}{l}\text { Proposed } \\
\text { Unit }\end{array}$ & $\begin{array}{l}\text { Classification Using } \\
\text { Discriminant Analysis }\end{array}$ \\
\hline USW GU-3 & 2657 & $C F M n$ & $z$ \\
\hline USW GU-3 & 2696 & CFMn & $z$ \\
\hline USW GU-3 & 2727 & TRW & d \\
\hline USW GU-3 & 2915 & $T R w$ & $d$ \\
\hline USW GU-3 & 2971 & TRW & d \\
\hline USW GU-3 & 3005 & TRW & d \\
\hline USW GU-3 & 3045 & TRW & $d$ \\
\hline USH GU-3 & 3113 & $T R w$ & $d$ \\
\hline USW G-4 & 2840 & TRW & $d$ \\
\hline USW $G-4$ & 2875 & TRW & d \\
\hline USW G-4 & 2947 & TRW & d \\
\hline USW G-4 & 3000 & $T R w$ & $d$ \\
\hline USW H-3 & 2490 & CFMn & $z$ \\
\hline USW WT-1 & 440 & PTn & $v$ \\
\hline USW WT-1 & 500 & $T S_{w 1} 1 / 2$ & d \\
\hline US' WT-1 & 550 & TSw1/2 & d \\
\hline USW WT-1 & 640 & $T S_{w 1} 12$ & 9 \\
\hline USW WT-1 & 690 & TSw1/2 & $d$ \\
\hline USW WT-1 & 780 & TSw1/2 & $d$ \\
\hline USW WT-1 & 840 & TSw1/2 & $d$ \\
\hline USW WT-1 & 930 & TSw1/2 & $v$ \\
\hline USW WT-1 & 1000 & TSw1/2 & d \\
\hline USW WT-1 & 1090 & TSw1/2 & d \\
\hline USW WT-1 & 1160 & TSw1/2 & $d$ \\
\hline USW WT-1 & 1220 & $T S w 1 / 2$ & $d$ \\
\hline USW WT-1 & 1300 & TSw1/2 & $d$ \\
\hline USW WT-1 & 1320 & $\mathrm{CHn}(\mathrm{z})$ & $z$ \\
\hline USW WT-1 & 1340 & $\mathrm{CHn}(\mathrm{z})$ & $z$ \\
\hline USW WT-1 & 1380 & $\mathrm{CHn}(\mathrm{z})$ & $z$ \\
\hline USW WT-I & 1410 & CHn( $\mathrm{z})$ & $z$ \\
\hline USW WT-1 & 1470 & $\mathrm{CHn}(\mathrm{z})$ & $z$ \\
\hline USW WT-i & 1510 & $\mathrm{CHn}(\mathrm{z})$ & $z$ \\
\hline USW WT-1 & 1550 & $\mathrm{CHn}(\mathrm{z})$ & $z$ \\
\hline USW WT-1 & 1570 & $\mathrm{CHn}(\mathrm{z})$ & 2 \\
\hline USW WT-2 & 250 & PTn & $v$ \\
\hline USW WT-2 & 260 & TSw1/2 & $d$ \\
\hline USW WT-2 & 290 & TSWI/2 & $d$ \\
\hline
\end{tabular}




\begin{tabular}{|c|c|c|c|}
\hline $\begin{array}{l}\text { Dr ill } \\
\text { Hole }\end{array}$ & Depth & $\begin{array}{l}\text { Proposed } \\
\text { Unit }\end{array}$ & $\begin{array}{l}\text { Classification Using } \\
\text { Discriminant Analysis }\end{array}$ \\
\hline $\begin{array}{l}\text { USW WT-2 } \\
\text { USW WT-2 } \\
\text { USW WT-2 } \\
\text { USW WT-2 } \\
\text { USW WT-2 } \\
\text { USW WT-2 } \\
\text { USW WT-2 } \\
\text { USW WT-2 } \\
\text { USW WT-2 } \\
\text { USW WT-2 } \\
\text { USW WT-2 } \\
\text { USW WT-2 } \\
\text { USW WT-2 } \\
\text { USW WT-2 } \\
\text { USW WT-2 } \\
\text { USW WT-2 } \\
\text { USW WT-2 } \\
\text { USW WT-2 } \\
\text { USW WT-2 } \\
\text { USW WT-2 } \\
\text { USW WT-2 } \\
\text { USW WT-2 } \\
\text { USW WT-2 } \\
\text { USW WT-2 } \\
\text { USW WT-2 } \\
\text { USW WT-2 } \\
\text { USW WT-2 } \\
\text { USW WT-2 } \\
\text { USW WT-2 } \\
\text { USW WT-2 }\end{array}$ & $\begin{array}{l}420 \\
510 \\
570 \\
650 \\
720 \\
780 \\
850 \\
930 \\
990 \\
1060 \\
1130 \\
1190 \\
1200 \\
1250 \\
1300 \\
1360 \\
1420 \\
1450 \\
1470 \\
1520 \\
1570 \\
1640 \\
1710 \\
1750 \\
1820 \\
1910 \\
2000 \\
2050 \\
2054 \\
2059\end{array}$ & $\begin{array}{l}\text { TSw1/2 } \\
\text { TSw1/2 } \\
\text { TSw1/2 } \\
\text { TSw1/2 } \\
\text { TSw1/2 } \\
\text { TSw1/2 } \\
\text { TSw1/2 } \\
\text { TSw1/2 } \\
\text { TSw1/2 } \\
\text { TSw1/2 } \\
\text { TSwl/2 } \\
\text { TSw3 } \\
\text { TSw3 } \\
\text { CHn(v) } \\
\text { CHn(v) } \\
\text { CHn(v) } \\
\text { CHn(v) } \\
\text { CHniv) } \\
\text { CHn(v) } \\
\text { CHn(z) } \\
\text { CHn(z) } \\
\text { PPw } \\
\text { PPw } \\
\text { PPw } \\
\text { CFUn } \\
\text { CFUn } \\
\text { CFUn } \\
\text { BFw } \\
\text { BFw } \\
\text { BFw }\end{array}$ & $\begin{array}{l}d \\
d \\
d \\
d \\
d \\
d \\
d \\
d \\
d \\
d \\
d \\
v \\
v \\
v \\
v \\
v \\
v \\
d \\
v \\
z \\
z \\
d \\
d \\
d \\
z \\
z \\
z \\
v \\
d \\
d\end{array}$ \\
\hline $\begin{array}{l}J-12 \\
J-12 \\
J-12 \\
J-12 \\
J-12 \\
J-12 \\
J-12 \\
J-12 \\
J-12 \\
J-12 \\
J-12\end{array}$ & $\begin{array}{r}620 \\
650 \\
710 \\
770 \\
860 \\
905 \\
983 \\
1067 \\
1093 \\
1121 \\
1136\end{array}$ & $\begin{array}{l}\text { PTn } \\
\text { TSw1/2 } \\
\text { TSw1/2 } \\
\text { TSw1/2 } \\
\text { TSw1/2 } \\
\text { TSw1/2 } \\
\text { TSw1/2 } \\
\text { TSw1/2 } \\
\text { TSw3 } \\
\text { TSw3 } \\
\text { CHn(z) }\end{array}$ & $\begin{array}{l}v \\
d \\
d \\
d \\
d \\
d \\
d \\
d \\
v \\
v \\
z\end{array}$ \\
\hline $\begin{array}{l}\mathrm{J}-13 \\
\mathrm{~J}-13 \\
\mathrm{~J}-13 \\
\mathrm{~J}-13 \\
\mathrm{~J}-13 \\
\mathrm{~J}-13\end{array}$ & $\begin{array}{l}427 \\
492 \\
591 \\
607 \\
689 \\
801\end{array}$ & $\begin{array}{l}\text { TCw } \\
\text { TCw } \\
\text { PTn } \\
\text { PTn } \\
\text { TSw1/2 } \\
\text { TSw } 1 / 2\end{array}$ & $\begin{array}{l}d \\
d \\
v \\
v \\
d \\
d\end{array}$ \\
\hline
\end{tabular}




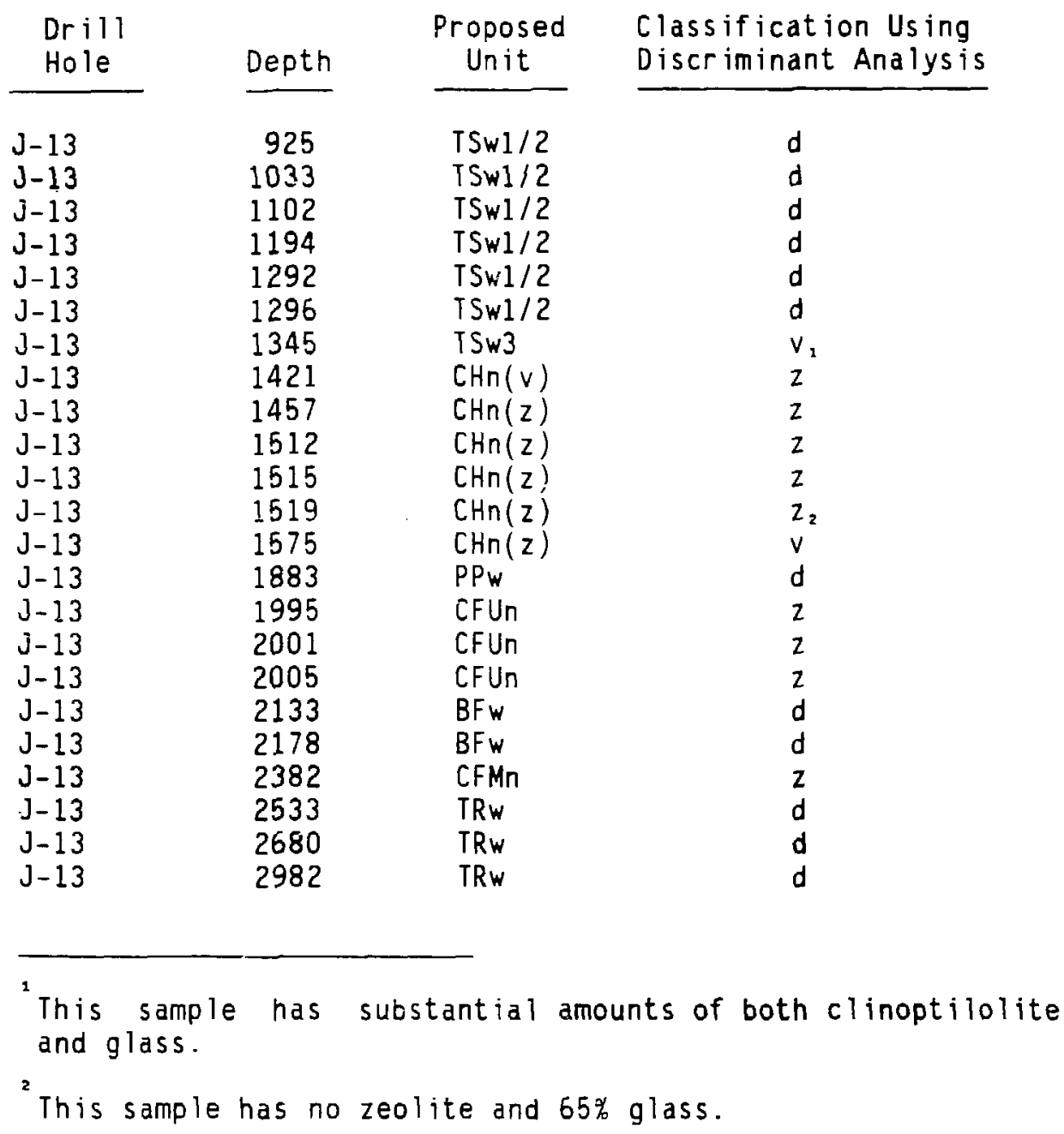




\begin{tabular}{|c|c|c|c|c|}
\hline Unit & Hole & $\begin{array}{l}\text { Samp le } \\
\text { Type }\end{array}$ & $\begin{array}{c}\text { Number of } \\
\text { Samples }\end{array}$ & Tota 1 \\
\hline $\mathrm{CHn} 1$ & $\begin{array}{l}\text { USW G-1 } \\
\text { USW G-2 } \\
\text { USW G-4 } \\
\text { USW H-4 } \\
\text { UE-25a\#1 }\end{array}$ & $\begin{array}{l}\text { Core } \\
\text { Core } \\
\text { Core } \\
\text { Sidewall } \\
\text { Cuttings } \\
\text { Cole }\end{array}$ & $\begin{array}{r}6 \\
15 \\
9 \\
3 \\
4 \\
3\end{array}$ & 40 \\
\hline $\mathrm{CH} \cap 2$ & $\begin{array}{ll}\text { USW } & \text { G-1 } \\
\text { USW } & \text { G-4 } \\
\text { USW } & H-5\end{array}$ & $\begin{array}{l}\text { Core } \\
\text { Core } \\
\text { Sidewall } \\
\text { Cuttings }\end{array}$ & $\begin{array}{l}4 \\
2 \\
1 \\
1\end{array}$ & 9 \\
\hline $\mathrm{CH} n 3$ & $\begin{array}{ll}\text { USW } & G-1 \\
\text { USW } & G-4 \\
\text { USW } & H-4 \\
\text { USW } & H-5\end{array}$ & $\begin{array}{l}\text { Core } \\
\text { Core } \\
\text { Cuttings } \\
\text { Sidewall }\end{array}$ & $\begin{array}{l}1 \\
3 \\
1 \\
1\end{array}$ & 6 \\
\hline $\mathrm{CHn}(\mathrm{z})$ & $\begin{array}{l}J-1: \\
J-1: 3 \\
\text { USW WT-1 } \\
\text { USW WT-2 }\end{array}$ & $\begin{array}{l}\text { Cuttings } \\
\text { Core } \\
\text { Cutt ings } \\
\text { Cuttings }\end{array}$ & $\begin{array}{l}1 \\
5 \\
8 \\
2\end{array}$ & 16 \\
\hline CFUn & $\begin{array}{l}\text { USW G-1 } \\
\text { USW } G-2 \\
\text { USW GU-3 } \\
\text { USW } G-4 \\
\text { USW } H-3 \\
\text { USW H-4 } \\
\text { USW H-5 } \\
\text { J-13 } \\
\text { USW WT-2 }\end{array}$ & $\begin{array}{l}\text { Core } \\
\text { Core } \\
\text { Core } \\
\text { Core } \\
\text { Sidewall } \\
\text { Cuttings } \\
\text { Cuttings } \\
\text { Core } \\
\text { Cuttings }\end{array}$ & $\begin{array}{r}8 \\
3 \\
6 \\
10 \\
2 \\
2 \\
1 \\
3 \\
3\end{array}$ & 38 \\
\hline CFMn 1 & $\begin{array}{l}\text { USW G-1 } \\
\text { USW G-2 } \\
\text { USW GU-3 } \\
\text { USW G-4 } \\
\text { USW H-3 } \\
\text { UE-25b\#1H }\end{array}$ & $\begin{array}{l}\text { Core } \\
\text { Core } \\
\text { Core } \\
\text { Core } \\
\text { Sidewall } \\
\text { Core }\end{array}$ & $\begin{array}{l}2 \\
2 \\
3 \\
2 \\
2 \\
2\end{array}$ & 13 \\
\hline
\end{tabular}




\begin{tabular}{|c|c|c|c|c|}
\hline Unit & Hole & $\begin{array}{l}\text { Samp le } \\
\text { Type }\end{array}$ & $\begin{array}{c}\text { Number of } \\
\text { Samples }\end{array}$ & Total \\
\hline CFMn2 & $\begin{array}{l}\text { !ISW G-1 } \\
\text { USW G-2 } \\
\text { USW GU-3 } \\
\text { USW G-4 } \\
\text { UE-25b\#1H }\end{array}$ & $\begin{array}{l}\text { Core } \\
\text { Core } \\
\text { Core } \\
\text { Core } \\
\text { Core }\end{array}$ & $\begin{array}{l}3 \\
2 \\
1 \\
1 \\
3\end{array}$ & 10 \\
\hline CFMn3 & $\begin{array}{l}\text { USW G-1 } \\
\text { USW G-2 } \\
\text { USW G-4 } \\
\text { UE-25b\#1H }\end{array}$ & $\begin{array}{l}\text { Core } \\
\text { Core } \\
\text { Core } \\
\text { Core }\end{array}$ & $\begin{array}{l}4 \\
1 \\
4 \\
1\end{array}$ & 10 \\
\hline CFMn & $\begin{array}{l}\text { USW GU-3 } \\
\text { USW H-3 } \\
J-13\end{array}$ & $\begin{array}{l}\text { Core } \\
\text { Sidewal1 } \\
\text { Core }\end{array}$ & $\begin{array}{l}2 \\
1 \\
1\end{array}$ & 4 \\
\hline
\end{tabular}


APPENDIX D.

\section{CONSTRUCTION OF PROBABILISTIC MODELS}

As explained in Sec. II of the text, most analyses of the $x$-ray diffraction data have been carried out using the square roots of the abundances of the measured minerals in the samples as the basic observations. This transformation both reduces the tendency of the measurement error to increase with measured abundance in the raw data, reported as percentages by Bish and Vaniman (1985) and Bish and Chipera (1986), and makes some of the more skewed distributions a little more symmetric.

In constructing the models of Sec. IV, we have assumed that the square root data are not only fairly symmetric and homoscedastic, but even approximately normally distributed, so that the first two moments of the original proportions may be approximated in terms of the mean $\mu$ and variance $\sigma^{2}$ of the square roots by

$$
\text { Expected value }=100 e=\mu^{2}+\sigma^{2}
$$

and

$$
\text { Variance }=10,000 v=2 \sigma^{2}\left(\sigma^{2}+2 \mu^{2}\right) .
$$

(Use of the factors 100 and 10,000 here will simplify expressions below because the beta distribution uses proportions expressed as fractions rather than as percentages.)

Simple moment matching is used to determine the parameters of a corresponding beta distribution. The beta distribution, defined on the interval $(0,1)$, is a probability model frequently used to describe proportions. This model has two parameters and probability density function

$$
b(p)=\underset{(a) \Gamma(\beta)}{\Gamma(a+\beta)} p^{a-1}(1-p)^{\beta-1}, \quad 0<p<1
$$


where $\Gamma$ denotes the gamma function. That is, if this distribution is used to model the abundance (in percentage) of a mineral in a sample, the probability of observing not more than $P$ percent of the mineral in the sample is given by

$$
\int_{0}^{0.01 p} b(p) d p
$$

If $Y$ has a beta distribution with parameters $a$ and $\beta$, its first two moments are

$$
E(Y)=\frac{a}{a+\beta}
$$

and

$$
V(Y)=\frac{a \beta}{(a+\beta+1)(a+\beta)^{2}} .
$$

To obtain the beta distribution with the moments e and $v$ of Eqs. (D.1) and (D.2), we solve the pair of equations

$$
E(Y)=e
$$

and

$$
V(Y)=V
$$

for $a$ and $\beta$ to get

$$
a=\left[\frac{e(1-e)}{v}-1\right] e
$$


and

$$
\beta=\left[\frac{e(1-e)}{v}-1\right](1-e)
$$

These identities were used to obtain the models in Tables 2 through 6.

The beta distribution is the marginal of a multivariate Dirichlet distribution, which has been widely used to model compositional data. However, its inadequacies are numerous and amply catalogued, for example in the monograph by Aitchison (1986). Logistic normal distributions form a far richer class with much more satisfactory properties, and future work will emphasize their use in the construction of multivariate models for simulation purposes.

When, as in the models for clinoptilolite and mordenite in section IV, a quantity is modeled as the product of two independent random variables with means $\mu$ and $\nu$ respectively, and variances $\sigma^{2}$ and $\tau^{2}$, then the mean of the product is $\mu \nu$, and the variance of the product is

$$
\mu^{2} \tau^{2}+\nu^{2} \sigma^{2}+\sigma^{2} \tau^{2}
$$

These identities were used to obtain the values in Tables 3 and 5. 


\section{REFERENCES}

Aitchison, 3., The Statistical Analys is of Compositional Data (Chapman and Hall, London, 1986).

Bish, D. L. and S. Chipera (1986), "Mineralogy of Orill Holes J-13, UE-25a\#1 and USW G-1 at Yucca Mountain, Nevada", Los Alamos National Laboratory report LA-10764-MS.

Bish, D. L., A. E. Ogard and D. T. Vaniman (1984), "Mineralogy-Petrology and Groundwater Geochemistry of Yucca Mountain Tuffs", Materials Research Society Symposium Procedings 26, pp. 283-291.

Bish, D. L. and D. T. Vaniman (1985) "Mineralogic Summary of Yucca Mountain, Nevada", Los Alamos National Laboratory report LA-10543-MS.

Daniels, W. (ed.) (December, 1982), "Summary Report on the Geochemistry of Yucca Mountain and Environs", Los Alamos National Laboratory report LA-9328-MS.

Ortiz, T. S., R. L. Williams, F. B. Nimick, B. C. Whittet and D. L. South (1985), "A Three-Dimensional Model of Reference Thermal/Mechanical and Hydrological Stratigraphy at Yucca Mountain, Southern Nevada", Sandia National Laboratories report SAND84-1076.

Scott, R. B. and J. Bonk (1984), "Preliminary Geologic Map of Yucca Mountain, Nye County, Nevada, with Geologic Sections", USGS-OFR-84-494. 